Canadian

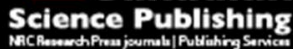

Canadian Geotechnical Journal Revue canadienne de géotechnique

\title{
The Influence of Lubricant Fluids on Swelling Behaviour of Queenston Shale In Southern Ontario
}

\begin{tabular}{|r|l|}
\hline Journal: & Canadian Geotechnical Journal \\
\hline Manuscript ID & cgj-2015-0300.R2 \\
\hline Danuscript Type: & Article \\
\hline Complete List of Authors: & $\begin{array}{l}\text { Al-Maamori, Hayder; University of Western Ontario, Civil and } \\
\text { Environmental Engineering } \\
\text { El Naggar, M. Hesham; University of Western Ontario, } \\
\text { Micic, S.; Geotechnical Research Centre } \\
\text { Lo, K.; Geotechnical Research Centre }\end{array}$ \\
\hline Keyword: & $\begin{array}{l}\text { micro-tunnelling, Queenston Shale, swelling, lubricant fluids, Time- } \\
\text { dependent deformation }\end{array}$ \\
\hline & \\
\hline
\end{tabular}

SCHOLARONE ${ }^{m}$

Manuscripts 
i) Title: The Influence of Lubricant Fluids on Swelling Behaviour of Queenston Shale In Southern Ontario

\section{ii) Authors:}

Hayder Mohammed Salim Al-Maamori

Mohamed Hesham El Naggar, P.Eng.

Silvana Micic, P.Eng.

K.Y. Lo, P.Eng.

\section{iii) Affiliation and address of author:}

Hayder Mohammed Salim Al-Maamori .... Ph.D. Candidate, Civil and Environmental Engineering Department, Western University. halmaamo@uwo.ca

Mohamed Hesham El Naggar ...... Professor, Civil and Environmental Engineering Department, Western University.

helnaggar@eng.uwo.ca

Silvana Micic ..... Adjunct Professor, Geotechnical Research Centre, Western University. smicic2@uwo.ca

K.Y. Lo ..... Professor Emeritus, Geotechnical Research Centre, Western University. cquintus@eng.uwo.ca

\section{iv) Correspondence author:}

Mohamed Hesham El Naggar, P.Eng.

Spencer Engineering Building, Room 2080, Western University. London, Ontario, Canada, N6A 3K7

Tel: +1 519-661-4219

Fax: +1 519-661-3808

helnaggar@eng.uwo.ca 


\begin{abstract}
The feasibility of micro-tunnelling technique to install pipelines through Queenston Shale of Southern Ontario is being investigated. In micro-tunnelling technique, lubricant fluids, such as bentonite slurry and polymer solution are used to facilitate excavation during the installation of the pipeline sections. In this regard, a comprehensive testing program was performed to investigate the time-dependent deformation behaviour of Queenston Shale considering lubricant fluids used in construction. The free swell test, semi-confined swell test, and the null swell test were utilized to perform this study. The results of 144 tests are presented and the variation of swelling characteristics of Queenston Shale in lubricant fluids and in water is briefly discussed. The swelling model suggested by Lo and Hefny (1996) was adopted to develop the swelling envelopes of Queenston Shale in lubricant fluids and water in both horizontal and vertical directions with respect to the rock bedding.
\end{abstract}

In comparison to swelling in fresh water, the study revealed that the polymers solution has substantially reduced the swelling of Queenston Shale in all directions, while the bentonite solution was less efficient in reducing the swelling of Niagara Queenston Shale, and has a slight negative influence on the swelling (i.e. increased swelling) of Milton Queenston Shale.

Key Words: micro-tunnelling, Queenston Shale, swelling, lubricant fluids. 


\section{Introduction}

The swelling phenomenon is a common expression of the deformation that occurs in some sedimentary rocks in Southern Ontario and elsewhere upon time after excavation in the rock mass. The Queenston Shale among other shaly sedimentary rocks in Southern Ontario exhibits considerably high swelling potential and time-dependent deformation. The swelling phenomenon can cause major problems to the underground structures, many of which were recorded in the form of invert heave and lateral inward deflection in several tunnels around the world (Lo and Yuen 1981).

The swelling phenomenon of shaly rocks in Southern Ontario was early recognized in 1903 when an inward deformation in the wheel pit walls at the Canadian Niagara falls was reported (Morison, 1957). Some of the shaly limestone in Southern Ontario, such as that in Thorold also exhibits considerable time-dependent deformation that caused severe cracks to develop in one of the walls of Thorold tunnel just after one year of construction (Bowen et al 1976). Similarly, the swelling of sedimentary rocks had caused distress in many tunnels in Europe in the form of invert heaves at a rate of hundreds mm per year (Einstein and Bischoff 1975).

The amount of swelling deformations and the mechanisms that control the swelling in different rock types are different. The hydration process of the anhydrites upon exposure to water controls the swelling deformation of the anhydrites. In this process, the anhydrites exhibit an increase in volume when transformed to gypsum upon hydration. In potash and rock salts, the mechanism that controls the swelling deformation is mainly the creep process. When potash and rock salts creep, the particles undergo a movement of dislocation that leads to gliding in the intra-crystalline structure. These changes are manifested in the form of swelling deformation. 
The observed swelling deformation of shales and marl when they are in contact with fresh water is mainly attributed to the osmoses and diffusion processes due to the ion concentration differences between the double layer water within the rock and the external free water surrounding the rock (Einstein and Bischoff 1975). The osmoses and diffusion processes as the controlling mechanism of the swelling deformation of Queenston Shale from Southern Ontario was reinforced through the research performed by Lee and Lo (1993). They performed different swelling tests on Queenston and other shales from Southern Ontario in water with variable concentrations of $(\mathrm{NaCl})$ solutions and other fluids and concluded that three conditions should be met in order for swelling of Queenston Shale to occur: a) the relief of the initial stresses upon excavation; b) the accessibility of water; and c) an outward salts concentration gradient from the rock pore fluid to the ambient fluid. Lo and co-workers extensively investigated the swelling of shales. Lo et al. (1975 and 1978) measured and quantified the time-dependent deformations of shaly rocks in Southern Ontario. They developed laboratory test methods to measure the swelling strains of rocks considering the confining pressure, and showed that these methods can produce results consistent with field measurements. These test methods were utilized in subsequent researches to investigate the swelling behaviour of shaly rocks including Queenston Shale (Lo and Lee 1990; Lee and Lo 1993; Hefny et al. 1996; Lo and Hefny 1996; and Hawlader et al. 2003). In these studies, the swelling anisotropy, swelling stress-dependency, swelling mechanism and the stress-strain time-dependency of Queenston Shale and other shales from Southern Ontario were extensively investigated. These studies used fresh water as the ambient fluid and the results were employed to identify the swelling mechanism of Queenston Shale in order to develop a rheological model and theoretical solutions for the deformation of these swelling shales and the associated stresses that act on the built structures. Al-Maamori et al. (2014) compiled the 
geo-mechanical properties of rocks in Southern Ontario and indicated the necessity to investigate the swelling behaviour of swelling rocks in drilling fluids and lubricant fluids.

\section{Objectives and Scope of Work}

This paper is part of a comprehensive research being performed in Western University to investigate the workability of micro-tunnelling technique in Queenston Shale of Southern Ontario. In this paper, the influence of lubricant fluids on the swelling behaviour of Queenston Shale, in comparison to fresh water, was investigated. The free swell, semiconfined swell and the null swell tests developed at Western University by Lo et al (1975 and 1978), Wai (1977), and Lo and Hefny (1999) were utilized to conduct the extensive testing program. The free swell test, semi-confined swell test, and null swell test were performed on vertically and horizontally cut specimens from Milton Queenston Shale and Niagara Queenston Shale submerged in water, polymers solution and bentonite solution. The tests results have revealed that using lubricant fluids, such as polymers and bentonite solutions can significantly influence the swelling behaviour of Milton Queenston Shale and Niagara Queenston Shale in comparison to their behaviour in water. Additional complementary mineralogical and chemical tests were performed to assist in explaining the swelling behaviour of both shales in lubricant fluids. The average values of the swelling tests results are presented in the framework of Lo and Hefney (1996) model to illustrate the variation in swelling behaviour of Queenston Shale in lubricant fluids and in water.

\section{Source of Rocks Samples}

The test program was performed on Queenston Shale samples from Milton and Niagara Falls in Southern Ontario. The Milton Queenston Shale samples were collected from a single borehole drilled at the construction site near the interchange between Regional Road 25 and Louis St. Laurent Avenue from the depth of $16.15 \mathrm{~m}$ to $34.52 \mathrm{~m}$ below the ground surface in 
Milton. The Niagara Queenston Shale samples were collected from two boreholes drilled in Niagara Tunnel, approximately $3.00 \mathrm{~m}$ to $12.00 \mathrm{~m}$ deep from the tunnel invert at the lowest part of the tunnel (i.e. $125 \mathrm{~m}$ to $137 \mathrm{~m}$ below the ground level). The Milton Queenston Shale samples were HQ size (i.e. $63 \mathrm{~mm}$ in diameter), while Niagara Queenston Shale samples were HQ3 size (i.e. $60.5 \mathrm{~mm}$ in diameter).

\section{Preserving Recovered Rocks}

To preserve the rock core in in-situ condition an established procedure developed at the Geotechnical Research Centre of Western University was followed. The recovered rock column was wrapped with saran wrap layer, and then with another coating layer of electrical tape to maintain moisture. A third layer of a bubble wrap was then added to jacket the rock column prior to placing it inside a hard PVC pipe that was cut to fit each rock piece. The PVC pipes were fitted with end caps and flexible rubber top and bottom discs placed on both ends of each rock column piece followed by a mechanical clamp. In this procedure, the recovered rock column was preserved safely against loosing moisture and against breakage during handling and transporting process.

\section{Samples Cutting}

In order to ensure consistency of the orientation of the specimens in measuring the swelling deformations in the orthogonal horizontal directions with respect to the rock bedding, the rock cores were marked with an indication line along the longitudinal axis immediately after recovered from the ground. The Queenston Shale specimens were cut using a diamond slab saw (Hillquest, USA) that utilizes mineral oil (Pella type A from Shell, Canada) for cooling, to produce vertically-cored specimens. The Queenston Shale cores were re-cored horizontally in the lab using the re-coring machine to produce horizontal Queenston Shale specimens. The 
indication line marked in the rock cores was used as reference to ensure that all horizontally re-cored specimens were from the same direction. Immediately after cutting, the specimens were thoroughly wiped with a piece of cloth and Trichloroethylene T340-4 solution (from Fisher Scientific, Canada) to remove any adhered spots of oil. The Queenston Shale specimens were cut and prepared in accordance with the requirements of (ASTM D45432008). The weight and dimensions of each Queenston Shale specimen were measured immediately after cutting to determine the density. In addition, for each Queenston Shale specimen a supplementary piece was cut from the rock core just next to the specimen in order to be used for the determination of the initial values of the moisture content, the pores salinity and the calcite content.

\section{Testing Methodology}

The swelling behaviour of Queenston Shale from Southern Ontario was extensively investigated (Lo et al. 1978; 1984; Lo 1986; Lee 1988; Huang 1993; Hefney et al. 1996; and Hawlader et al. 2003). However, the behaviour of these shales in lubricant fluids, such as bentonite and polymer solutions, that are utilized in micro-tunnelling technique is still lacking. Installing a pipeline using micro-tunnelling technique may last for several weeks before the utilized lubricant fluids are replaced with the cement grout. During this period, the excavated ground is in direct contact with these lubricant fluids. In order to investigate the swelling behaviour of Queenston Shale in lubricant fluids, free swell test, semi-confined swell test and null swell test were employed. These swelling tests were conducted using the polymer solution, the bentonite solution and fresh water as ambient fluids that surround Queenston Shale samples during the test period. 
Lubricant Fluids: The adopted ambient fluids used in this research are utilized in the microtunnelling drilling process in rocks as lubricant fluids including: the bentonite solution and the polymer solution, in addition to fresh water as the standard ambient fluid for swell tests. The mixing proportions were the same as those used in the field (i.e. $8 \%$ of bentonite/tap water by weight, and $0.8 \%$ of polymers/tap water by volume). The used bentonite was HYDRAUL-EZ (borehole stabilizer and lubricant, sodium bentonite clay from CETCOUSA), and the used polymer was TK60 (liquid polymer concentrate, anionic polyacrylamide suspension in a water-in-oil emulsion from Morrison Mud, Division of Mudtech Ltd.-UK). The bentonite and polymer solutions were prepared by gradually adding the required amount of bentonite or polymers to the corresponding amount of tap water with continuous mixing using high speed electrical mixer until a consistent uniform solution was achieved. The solutions were kept for a minimum of 24 hours before using according to the manufacturer's instructions to ensure full dispersion of the suspension particles in water and to avoid flocculation.

Tests for Swelling Behaviour: To investigate the swelling behaviour of Milton Queenston Shale and Niagara Queenston Shale in lubricant fluids, three swell tests were employed: free swell test, semi-confined swell test (Lo et al. 1978); and null swell test (Lo and Hefny 1999). These swell tests were originally developed in the Geotechnical Research Centre at Western University. For detailed description of the tests apparatus and tests procedures see (Lo and Hefny 1999). The free swell test was performed to investigate the swelling behaviour of Milton Queenston Shale and Niagara Queenston Shale in lubricant fluids when no confining stress was applied on specimens during the test. The semi-confined swell test was performed to investigate the stress-dependency of the swelling behaviour of Milton Queenston Shale and Niagara Queenston Shale in lubricant fluids. In this test, specimens were subject to different 
confining stresses while the corresponding swelling strains in the same direction of the applied stresses were measured. The null swell test was performed on specimens from Milton Queenston Shale and Niagara Queenston Shale to measure the pressure that was required to supress the swelling of specimens in the direction of the applied pressure when they were submerged in lubricant fluids. The standard ambient fluid in these tests was water. To investigate the anisotropy of the swelling behaviour of Milton Queenston Shale and Niagara Queenston Shale in lubricant fluids, the semi-confined swell test and null swell test were performed on vertically-cored and horizontally-cored specimens with respect to the rock bedding. While in the free swell test, the swelling strains were measured for each specimen in the vertical direction and in two orthogonal horizontal directions with respect to the rock bedding.

\section{Complementary Tests}

Additional complementary tests were performed on most tested swelling specimens. These complementary tests are important in assessing the Queenston Shale swelling behaviour in the adopted lubricant fluids.

\section{Mineralogical Tests}

X-Ray Diffraction: In order to determine the mineralogical composition of Milton Queenston Shale and Niagara Queenston Shale, X-Ray diffraction analyses were performed on four specimens of Milton Queenston Shale and two specimens of Niagara Queenston Shale that were selected from different depths to represent the entire rock column. These analyses were performed on randomly oriented powder (bulk) specimens and on oriented clay minerals (wet) specimens that include the separated clay-size portion only. The bulk specimens were prepared following the procedure described by Zhang et al. (2003), while the wet specimens were prepared following the procedure proposed by Moore and Reynolds (1989). The X-Ray 
diffraction analyses were performed using Rigaku rotating-anode X-Ray Diffractometer. It employed $\mathrm{CoK} \alpha$ radiation, with monochromation achieved using a curved crystal, diffracted beam and graphite monochromator. The instrument was operated at $45 \mathrm{kV}$ and $160 \mathrm{~mA}$, using the normal scan rate of $10^{\circ}$ two-theta per minute (equivalent to $0.5^{\circ}$ two-theta on conventional diffractometers). X-rays were collimated using $1^{\circ}$ divergent and scatter slits, and a $0.15 \mathrm{~mm}$ receiving slit. Bulk sample scans were completed from $2^{\circ}$ to $82^{\circ}$ two-theta, at a rate of 10 degree/minute.

The mineralogical composition of the tested Milton Queenston Shale and Niagara Queenston Shale was assessed using the semi-quantitative X-Ray diffraction analyses following Bragg's Law. The specimens from Milton Queenston Shale were taken from depths: 16.570, 21.158, 25.140 and $31.039 \mathrm{~m}$ from the borehole in Milton. The Niagara Queenston Shale specimens were taken from depths: 6.100 and $11.200 \mathrm{~m}$ from two boreholes drilled at the tunnel invert at the lowest point in the Niagara Tunnel. The approximate percentage of each mineral was calculated by dividing the area of the most intense mineral's peak by the sum of areas of all minerals' peaks at their largest intensities. Due to the difficulty in identifying the minerals in clay-size crystals, additional X-Ray diffraction traces were obtained for the separated claysize fraction specimens. The X-Ray diffraction traces for the bulk and the clay-separated fractions for both Milton Queenston Shale and Niagara Queenston Shale are shown in Fig. 1, and the results of the X-Ray diffraction analyses are summarized in Table 1.

In the process of identifying and quantifying the clay-size minerals, the corrections on the percentages of chlorite, illite and kaolinite suggested by Hein and Longstaffe (1983) were applied. The Chlorite has a basal series of diffraction that peaks on the first order reflection of 14.2 $\AA$. When heating the specimen to $550 \mathrm{C}^{\circ}$ for one hour, the first order peak became sharper and stronger while peaks at the second, third and fourth orders became weaker and 
may be eliminated (Moore and Reynolds 1989) as revealed from Figs. 1-b, and 1-d for traces of the separated clay-size fraction of Milton Queenston Shale and Niagara Queenston Shale, respectively. However, the peak intensity of Chlorite at the first, second, and third orders reflection in the X-Ray diffraction traces of Niagara Queenston Shale is slightly higher than that in Milton Queenston Shale, which indicates higher presence of Chlorite salt in Niagara Queenston Shale. The illite was identified in both Milton Queenston Shale and Niagara Queenston Shale through the maintained peaks at $10.06 \AA$ of the saturated specimens with ethylene glycol vapor and the heated specimens to $300 \mathrm{C}^{\circ}$ and $550 \mathrm{C}^{\circ}$, respectively. The peaks' intensities of Niagara Queenston Shale are greater than Milton Queenston Shale, indicating higher percentage of illite in Niagara Queenston Shale. The illite content of Niagara Queenston Shale ranges between 16.3\%-23.0\%, which is almost double the amount of illite in Milton Queenston Shale.

The distinct behaviour of kaolinite is clearly indicated in the traces of both Milton Queenston Shale and Niagara Queenston Shale specimens, where the first order reflection peak at $7.14 \AA$ disappears after heating the specimens to $550 \mathrm{C}^{\circ}$ for two hours. The Niagara Queenston Shale has slightly higher percentage of kaolinite than Milton Queenston Shale, as indicated in Table 1. Although kaolinite possesses relatively low swelling capacity, it may contribute in resulting higher swelling deformation of Niagara Queenston Shale in comparison to Milton Queenston Shale. The feldspar was identified through the first order reflection at $32.35^{\circ} 2 \theta$ in the traces of the bulk specimen. Moore and Reynolds (1989) suggested that the feldspar that reflects at this angle is potassium-rich monoclinic feldspar from the orthoclase family. The presence of the feldspar in Milton Queenston Shale is somewhat greater than in Niagara Queenston Shale, as indicated in the X-Ray diffraction traces in Fig. 1-a and Fig. 1-c. 
The low, or $\alpha$-quartz, is by far the most common silica minerals in sedimentary rocks. The large amounts of quartz in the $(<2 \mu \mathrm{m})$ fraction, for properly prepared samples, indicates the presence of either a glacial rocks flour or siliceous micro-fossil type, such as radiolarians and diatoms (Moore and Reynolds 1989). According to the X-Ray diffraction traces of both Milton Queenston Shale and Niagara Queenston Shale, the first and second order peaks of the quartz happen at $4.28 \AA$ and $3.35 \AA$ respectively. The presence of $\alpha$-quartz in Niagara Queenston Shale is about 25-32\% greater than in Milton Queenston Shale, and generally it forms about 45-60\% of the minerals of both Queenston Shales.

The calcite peaks in the second order were at $3.03 \AA$, and $3.04 \AA$ in the traces of bulk specimens for Milton Queenston Shale and Niagara Queenston Shale, respectively. The second order peaks were the strongest, and therefore they were used in predicting the percentage of calcite. The X-Ray diffraction analyses revealed that the percentage of calcite in Milton Queenston Shale is more than double in comparison to that in Niagara Queenston Shale. The results of the semi-quantitative determination of the calcite contents from the XRay diffraction analyses, summarized in Table 1, strongly agree with the results of the quantitative determination of carbonates using the gasometric (Chittick) apparatus. The strong agreement in the results of both analyses promotes the confidence in the predicted minerals from the semi-quantitative X-Ray diffraction analyses. The percentage of dolomite was derived from the third, and second order peaks at $2.9 \AA$ and $3.67 \AA$, in the traces of bulk specimens of Milton Queenston Shale and Niagara Queenston Shale, respectively. The dolomite content determined from the X-Ray diffraction analyses agree fairly with the results from Chittick apparatus, except for two Milton Queenston Shale specimens at depths 16.57 and $25.14 \mathrm{~m}$. The slight difference may be attributed to the disturbance that might have occured during sample preparation of the bulk specimens. The amount of the dolomite in 
Milton Queenston Shale is almost double the amount of the dolomite in Niagara Queenston Shale, as indicated in Table 1. The existence of both calcite and dolomite in the Queenston Shale governs the swelling deformation of these rocks. These carbonates form concretionary masses in the Queenston Shale, resulting in more resistive micro-structure to the swelling deformations. The greater the calcite content in the shaly rocks, the lower the value of swelling deformation (Lo et al. 1987).

The pyrite has first order reflection peak at $2.71 \AA$, as indicated in the X-Ray diffraction traces in Fig. 1. The amount of the existing pyrite is quite similar in Niagara Queenston Shale and Milton Queenston Shale, and it ranges between 2.2 -3.7\%. The minerals that exist in both Queenston Shales are listed with their percentages in Table 1. It is quite obvious that there are no gypsum and anhydrites that may cause a considerable volume change upon contact with water. On the one hand, the amounts of illite and chlorite are higher in Niagara Queenston Shale than in Milton Queenston Shale, and on the other hand, the amounts of the calcite and the dolomite in Milton Queenston Shale are more than double their amounts in Niagara Queenston Shale. This mineralogical combination in both Milton Queenston Shale and Niagara Queenston Shale may cause a considerable variation in the swelling deformations of both of the shales.

Scanning Electron Microscopy (SEM): The scanning electron microscopy was performed using Hitachi S-3400N Variable Pressure SEM machine on four sets of Milton Queenston Shale specimens of orientations parallel and perpendicular to the rock beddings (i.e. horizontally and vertically cut specimens). One set of these specimens was cut from intact Milton Queenston Shale while the other sets were cut from terminated swelling tests in fresh water, bentonite and polymer solutions. The specimens were cut in dry condition using a thin blade diamond saw without cooling agent to avoid washing of bentonite and polymers. The 
cut specimens were mounted on the metal base of the SEM machine using adhesive epoxy. In order to produce clear images, the specimens were coated with a very thin layer of gold using gold sputter coater. The scanning electron microscopy was performed at three spots on each specimen: a) at the outer surface of the specimen, which was in direct contact with the ambient fluid; b) at $15 \mathrm{~mm}$ away from the specimen's surface towards the centre; and c) at 30 mm way from the surface towards the specimen's centre, (i.e. near the centre). The sample preparation and locations of imaging are illustrated schematically in Figure 2.

The Scanning electron microscopy images taken at the outer surface of Milton Queenston Shale specimens after terminating the free swell test in bentonite and polymer solutions are presented in Figures 3-a to 3-d. The dark colour mass represents Milton Queenston Shale, while the white-grey colour on the surface of the specimen represents either bentonite or polymer particles, which were accumulated during the free swell test. The accumulation of bentonite and polymers particles has resulted in the formation of coating layers on the outer surface of Milton Queenston Shale specimens. These coating layers might have been acting as barriers that have relatively reduced further penetration of water particles, which exist in the ambient fluid, into Milton Queenston Shale specimens. Comparing the images for the specimens exposed to bentonite and polymers solutions, it is noted that the coating layer of polymers particles is considerably thicker than the coating layer of the bentonite particles. The images indicate that the polymers' particles penetrate deeper into the surfacial microcracks of Milton Queenston Shale, forming thick surface coating layer, as indicated in Figure 3-a and Figure 3-b, which effectively sealed the outer surface of Milton Queenston Shale, and hence reducing the swelling of Milton Queenston Shale in polymers solution, as it will be presented in the swelling results. 
Figures 4 and 5 compare the micro-structure of Milton Queenston Shale in vertical and horizontal directions, respectively, with respect to the rock beddings, before and after the exposure to the ambient fluids. Figure 4-a shows that the outer surface of intact Milton Queenston Shale specimen had micro-cracks, which may be attributed to the sample disturbance during the cutting process because the images of the spots away from surface (Figures 4-b and 4-c) do not show micro-cracks. Figures 4-d, 4-e and 4-f show the vertical sections in Milton Queenston Shale after terminating the free swell test in polymers solution. In comparison to the intact specimen, the micro-cracks near the outer surface of the specimen are relatively wider and spread deeper into the specimen up to $15 \mathrm{~mm}$ from the outer surface. It can be also noted from Figure 4-e that polymers' particles accumulated on the micro-cracks boundaries, forming a micro-film that may prevent the water from moving deeper into the specimen (Figure 4-f). Figures 4-g, 4-h, and 4-i show that the micro-cracks developed along the entire width of the specimen after the exposure to the bentonite solution. These microcracks resulted in more swelling deformations. The effect of water as ambient fluid on Milton Queenston Shale is manifested in Figures 4-j, 4-k, and 4-1, which show the micro-cracks widening near the surface of the specimen up to $15 \mathrm{~mm}$ away from the surface. At the spcimen centre, the micro-pores were enlarged, but there was no formation of new microcracks.

Based on the observations above, it can be concluded that both bentonite solution and fresh water have similar effects on Milton Queenston Shale, and expanded the surface microcracks, compared to the polymers solution. At $15 \mathrm{~mm}$ from the outer surface, the bentonite solution resulted in the widest micro-cracks. While no micro-cracks can be noticed at the specimen center, the micro-pores at the centre of the specimen exposed to water were enlarged in volume. 
Figure 5 shows the scanning electron microscopy images made on horizontal sections (i.e. parallel to rock bedding) of the same specimens. The fabric of Milton Queenston Shale in the horizontal direction appears more compact, and has less disturbance than the vertical direction (Figure 5-a, 5-b and 5-c). The overall effect of ambient fluids on the micro-structure of Milton Queenston Shale in the horizontal direction is similar, but less in magnitude, compared to the vertical direction. The bentonite solution caused the widest micro-cracks across the entire depth of the specimen, as indicated in Figure 5-g, 5-h, and 5-i, while the polymers solution caused the least micro-cracks and only near the surface as indicated in Figure 5-d. The fresh water had significant effect near the surface (Figure 5-j), but its effect was less than bentonite solution at deeper spots (Figures 5-k and 5-1).

Cation Exchange Capacity test (CEC): The cation exchane capacity generally referes to the quantity of the measured cations that are reversibly adsorbed (expressed as moles of positive charge) per unit weight of mineral (McBride 1994). In the sedimentary rocks that involve clayey minerals, the cation exchange capacity is representative of the concentration of unfixed cations in the interlayers and surface layers (diffuse layer) of the mineral, which depends on the magnitude of the total layer charge (structural plus surface). The cation exchange capacity can also be considered as a measure of the replacement of a given cation on a given surface by another cation, which can be of a similar valence (Evangelou 1998). The cation exchange capacity can be expressed in milliequivalents per 100 grams of powdered rock or soil, where the equivalent represents the cation molecular weight divided by its valence. 
The cation exchange capacity of Milton Queenston Shale and Niagara Queenston Shale was measured through mixing air-dried powder of Queenston Shale specimens with potassium chloride and ammonium acetate solutions of known concentrations, separately. The mixing continued for 24 hours to allow for the cations that exist in the specimens to exchange either with the potassium or ammonium cations in the solutions. The amounts of the freed cations in the solutions, such as potassium $\left(\mathrm{K}^{+}\right)$, sodium $\left(\mathrm{Na}^{+}\right)$, magnesium $\left(\mathrm{Mg}^{2+}\right)$; and calcium $\left(\mathrm{Ca}^{2+}\right)$, were then measured using a computerized inductively coupled plasma (ICP) analyzer (Vista Pro ICP-OES with a SPS-3 auto-sampler from Varian, Australia). The measured quantities of these cations represent the cation exchange capacity of Milton Queenston Shale and Niagara Queenston SHALE. In a similar manner, the cation exchange capacity of the bentonite solution, which was used as the ambient fluid in the swelling tests, was also measured. The cation exchange capacity was measured for Milton Queenston Shale and Niagara Queenston Shale before and after the exposure to the bentonite solution, as well as on fresh bentonite solution and bentonite solutions that were in direct contact with the Milton Queenston Shale and Niagara Queenston Shale during the swelling tests.

The average of the measured cation exchange capacity of the existing cations, such as Calcium $\left(\mathrm{Ca}^{2+}\right)$, Potassium $\left(\mathrm{K}^{+}\right)$, Magnesium $\left(\mathrm{Mg}^{2+}\right)$; and Sodium $\left(\mathrm{Na}^{+}\right)$, in Milton Queenston Shale, Niagara Queenston Shale, and bentonite solution, are summarized in Table 2. The results presented in Table 2 indicate that the cation exchange capacity of the Calcium $\left(\mathrm{Ca}^{2+}\right)$ increased in both Niagara Queenston Shale and Milton Queenston Shale, while the cation exchange capacity of the Magnesium $\left(\mathrm{Mg}^{2+}\right)$ decreased, after the exposure to the bentonite solution. The cation exchange capacity of both Potassium $\left(\mathrm{K}^{+}\right)$and Sodium $\left(\mathrm{Na}^{+}\right)$ decreased in Niagara Queenston Shale after the exposure to the bentonite solution, and the overall cation exchange capacity of Niagara Queenston Shale decreased by $15 \%$, from 45.13 to $38.3 \mathrm{meq} / 100 \mathrm{~g}$. In Milton Queenston Shale, the exposure to bentonite solution 
considerably increased cation exchange capacity of Sodium $\left(\mathrm{Na}^{+}\right)$and slightly decreased cation exchange capacity of Potassium $\left(\mathrm{K}^{+}\right)$, and the overall cation exchange capacity increased by $10.5 \%$, from 37.56 to $41.51 \mathrm{meq} / 100 \mathrm{~g}$. The overall cation exchange capacity of fresh bentonite increased from 10.38 to $12.00 \mathrm{meq} / 100 \mathrm{~g}$ after it was used in free swell tes test of Niagara Queenston Shale, while it decreased to $10.26 \mathrm{meq} / 100 \mathrm{~g}$ after it was used in free swell test of Milton Queenston Shale. These observations reveal that the diffusion of cations during the free swell test was from Niagara Queenston Shale to bentonite solution, but from bentonite solution to Milton Queenston Shale. This difference in diffusion direction between Niagara Queenston Shale and Milton Queenston Shale may explain the reversed influence of bentonite solution on swelling deformations of these shales, as it will be presented in the results of swelling tests.

\section{Ancillary Tests}

Determination of Calcite and Dolomite Contents: For each specimen of the free swell test, semi-confined swell test and null swell test, quantitative determination of calcite and dolomite content were performed using Chittick apparatus following the procedure described in Dreimanis (1962). For most specimens, the calcite and dolomite contents were determined before and after performing the swelling deformation tests. For each swelling deformation test specimen, an additional specimen was taken from the same rock core to determine the initial calcite and dolomite contents. The specimens were air dried for seven days and then were grinded and sieved on No. 200 ASTM Sieve $(75 \mu \mathrm{m})$. The portions finer than $75 \mu \mathrm{m}$ were used to perform the gasometric Chittick analyses. This test measures the volume of the evolved $\mathrm{CO}_{2}$ from the reaction of the hydrochloric acid and the carbonates in the specimen. This volume is used to calculate the corresponding percentages of calcite and dolomite in the 
specimen. The calcite and dolomite contents of most specimens were determined after the swelling deformation tests were terminated in order to evaluate the exact carbonates contents in each specimen.

The calcite and dolomite contents determined from Chittick apparatus are presented in Table 3 to Table 9 for Milton Queenston Shale and Niagara Queenston Shale, respectively. From these tables, it can be noted that the percentage of the calcite content in Milton Queenston Shale ranges between $12 \%$ to $37 \%$, and the majority of specimens have a calcite content of 20\%-25, while the calcite content of Niagara Queenston Shale was ranging between $7 \%$ and 10.5. It is quite clear that the percentage of the calcite content in Milton Queenston Shale is more than double that in Niagara Queenston Shale. The high presence of the calcite in Milton Queenston Shale forms concretionary masses in the microstructure of these shales resulting in more resistance to the swelling deformations. This resistance to deformation affects the swelling potential of Milton Queenston Shale. The calcite content and dolomite content of both Milton Queenston Shale and Niagara Queenston Shale from Chitteck apparatus were generally consistent with the semi-quantitative X-ray diffraction analyses.

Moisture Content Determination: The moisture content was determined according to ASTM (D2216-2010). For each free swell test, semi-confined swell test and null swell test, the moisture content of the test specimen was calculated before and after performing the swelling deformation test. The moisture content results of Milton Queenston Shale and Niagara Queenston Shale specimens are presented in Tables 3 to 9. The natural moisture content of Milton Queenston Shale ranged between 2\% and 3\%, while the natural moisture content of Niagara Queenston Shale was $0.9 \%$ to $1.6 \%$. The moisture contents of Milton Queenston Shale and Niagara Queenston Shale measured before and after the swelling tests were used to 
determine the pore water salinity of the specimens of both shales. It can be noted from the results of the moisture content of both Milton Queenston Shale and Niagara Queenston Shale, measured after performing the swelling tests, that the moisture content was generally increased, which indicates the occurrence of osmosis process. However, the magnitude of the increase in the moisture content was not similar in water, polymer solution, and bentonite solution for both shales.

Pore Water Salinity Determination: The pore water salinity of Milton Queenston Shale and Niagara Queenston Shale specimens was calculated before and after performing the swelling tests following an earlier established procedure as described by Lee (1988). The pore water salinity of both Queenston Shales specimens measured before and after the swelling tests are presented in Tables 3 to 9 . The percentage reduction in pore water salinity of Milton Queenston Shale and Niagara Queenston Shale specimens, due to the exposure to water, bentonite solution and polymer solution, during the swelling tests is also presented in Tables 3 to 9.

In general, the natural pore water salinity of Milton Queenston Shale ranged between $71 \mathrm{~g} / \mathrm{L}$ to $268 \mathrm{~g} / \mathrm{L}$, with an average of $100 \mathrm{~g} / \mathrm{L}$, while the natural pore water salinity of Niagara Queenston Shale specimens ranged between $290 \mathrm{~g} / \mathrm{L}$ and $435 \mathrm{~g} / \mathrm{L}$, with an average of 370 g/L. The results show that the pore water salinity of both Queenston Shales increases gradually with depth. The results also demonstrate that the percentage reduction in pore water salinity upon exposure of Milton Queenston Shale to the bentonite solution was higher than that for water, and the opposite is true for Niagara Queenston Shale. In Milton Queenston Shale, the pore water salinity of the specimens exposed to bentonite decreased by $69 \%-87 \%$ (average of 77\%) from its initial (natural) value, while specimens exposed to water experienced $48 \%-73 \%$ reduction in pore water salinity by $48 \%-73 \%$ (average of $65 \%$ ). For 
Niagara Queenston Shale, exposure to water decreased the pore water salinity by $65-76 \%$, averaging $70 \%$, while the exposure to bentonite solution decreased it by $48-55 \%$, averaging $50 \%$. This difference in behaviour between Milton Queenston Shale and Niagara Queenston Shale may be attributed to their mineralogical composition and the variation in their cations concentrations. The polymers solution, on the other hand, reduced affected pore water salinity of both Queenston Shales almost equally and resulted in lower average percentage of $31 \%$ and $25 \%$ for Milton Queenston Shale and Niagara Queenston Shale, respectively.

The presented pore water salinity measurements of Milton Queenston Shale and Niagara Queenston Shale are consistent with the conditions of swelling of Queenston Shale proposed by Lee and Lo (1993). They attribute the Queenston Shale swelling to the diffusion process of pore water salinity and the osmoses process that occurs between the shale pores and ambient fluids. The results obtained herein indicate diffusion of pore water salinity of both Milton Queenston Shale and Niagara Queenston Shale, manifested in reduction of pore water salinity, which occurred upon the exposure to water, bentonite solution and polymers solution. However, the amount of diffusion varied for the three ambient fluids.

Rate of Absorption of Water: The rate of absorption of water for Milton Queenston Shale and Niagara Queenston Shale was determined following the test method described in ASTM (C1585-2013). This test method is used to determine the rate of absorption (sorptivity) of water by hydraulic cement concrete through measuring the increase in the mass of a specimen resulting from absorption of water as a function of time when only one surface of the specimen is exposed to water. However, this test method was used in this research to measure the rate of absorption of water, polymer solution, and bentonite solution by Milton Queenston Shale and Niagara Queenston Shale. The specimens were cut into cylinders $50 \mathrm{~mm}$ high. The height and diameter of the specimen was measured to the nearest $0.001 \mathrm{~mm}$. The aim of this test was to evaluate the rate of absorption of Milton Queenston Shale and Niagara Queenston 
Shale under their natural moisture contents to simulate their in-situ conditions. Thus, the specimens were coated with paraffin wax from all around, leaving only the bottom of the specimens uncoated, where it would be in contact with the solution, and the weights of the specimens were recorded to the nearest $0.01 \mathrm{~g}$. The specimens were then placed in containers similar to those for the semi-confined tests and the null-swell tests. The specimens were seated on a plastic wire cage placed in the containers in order to have the solutions freely in contact with the bottom of the specimens. Fresh water was then added to one container while bentonite slurry and polymer solution were added to the other containers up to the required level. The containers were covered with plastic sheets to prevent evaporation of the solutions. The test was performed in a temperature controlled room with $10 \pm 1$ degree $\mathrm{C}^{\circ}$. The increase in specimen's weight was measured in time intervals up to eight days. The test was repeated in each solution for both Milton Queenston Shale and Niagara Queenston Shale to have the average value of the rate of absorption in water, bentonite solution and in polymers solution, when the successive tests produced consistent results.

The rate of absorbing water by Milton Queenston Shale and Niagara Queenston Shale from the ambient fluids (i.e. water, polymer solution, and bentonite solution) was measured in the first eight days and the results are presented in Table 10. The initial rate of absorption (initial sorptivity, $\mathrm{Si}$ ) was measured during the first hours of the test, while the secondary rate of absorption (secondary sorptivity, Sc) was measured during the next seven days of the test. It can be noted from Table 10 that both initial and secondary sorptivity of Niagara Queenston Shale in water was higher than that in polymers and bentonite solutions. Moreover, the initial and secondary sorptivity of Milton Queenston Shale in bentonite solution were relatively high, and were higher than that in water and polymers solution. The secondary sorptivity in polymers solution was the lowest for both Niagara Queenston Shale and Milton Queenston Shale $\left(<0.0005 \mathrm{~mm} / \sqrt{\mathrm{s}}_{\mathrm{s}}\right)$, while the secondary sorptivity of both Queenston Shales in water 
was approximately $0.001 \mathrm{~mm} / \sqrt{ }_{\mathrm{s}}$. Finally, the secondary sorptivity of Milton Queenston Shale in bentonite solution $\left(0.0011 \mathrm{~mm} / \sqrt{\mathrm{s}}_{\mathrm{s}}\right)$ was higher than the secondary sorptivity of Niagara Queenston Shale in bentonite solution $\left(0.0008 \mathrm{~mm} / \sqrt{\mathrm{s}}_{\mathrm{s}}\right)$. The relative rates of absorbing water of both Nigara Queenston Shale and Milton Queenston Shale in the ambient fluids presented in Table 10 are consistent with the swelling results that will be presented in the next section.

\section{Results and Discussion}

\section{Free Swell Test}

The results of the free swell tests performed on Milton Queenston Shale and Niagara Queenston Shale are presented in Table 3 and Table 4, respectively, in terms of vertical swelling potential (VSP) and horizontal swelling potential (HSP). The presented horizontal swelling potential was the average of the swelling potential in two orthogonal horizontal directions, (i.e. $\mathrm{x}$ and $\mathrm{y}$ directions). The vertical swelling potential and horizontal swelling potential were defined as the rate of swelling strain of rock specimen that occurs in the vertical direction and in two orthogonal horizontal directions, respectively, in a log cycle of time upon exposure to ambient fluid, (i.e. water, polymer solution, and bentonite solution), (Lo et al., 1978). The log cycle of time is defined as a time period between day 10 and day 100 from the beginning of the test, where most of swelling strains occur. The strain that occurs in the rock specimen during the first 10 days of the free swell test is not considered an accurate representation of the actual swelling strain of the specimen, and therefore it is disregarded. This period is required for the rock specimen to reach environmental equilibrium between in-situ and lab conditions (Lo et al., 1978).

In order to investigate the influence of the polymer and bentonite concentrations in lubricant fluids used in the micro-tunnelling process, free swell tests were performed on Milton 
Queenston Shale specimens submerged in different concentrations of solutions. In this group, a total of 21 free swell test was performed in polymer concentrations of $0.2,0.4,0.6,0.8,1.0$ and $1.2 \%$, bentonite concentrations of $2.4,2.8,3.2,3.6,4.0$ and $8.0 \%$, in mixed polymer and bentonite, and in fresh water. The results of these free swell tests are presented in Table 3. These results demonstrated that as the polymer concentration increased, the swelling strains of Milton Queenston Shale decreased, while the opposite, to some extent, was observed for bentonite solutions. The polymers solution with $0.8 \%$ concentration, which is used in some micro-tunneling applications, suppressed the swelling of Milton Queenston Shale in both vertical and horizontal directions significantly. Therefore, this polymer concentration was adopted for the rest of swelling tests in this research. Similarly, the bentonite solution with $8.0 \%$ concentration is adopted in the testing program because it is used in micro-tunneling projects to provide the required lubrication between the Queenston Shale and the outer surface of the pipe segments. Using higher concentrations of polymers and bentonite solutions may cause blockage of the slurry pipes and/or damage to the pumping system.

The results of free swell tests on Milton Queenston Shale in water, $0.8 \%$ polymers solution, and $8 \%$ bentonite solution are presented in Figure 6 . The slope of the best-fit straight line of the swelling strain versus log time curves in vertical and horizontal directions, during day 10 to day 100 represents vertical swelling potential and horizontal swelling potential, respectively. Figure 6 shows that the swelling of Milton Queenston Shale in the polymers solution was significantly reduced in both directions in comparison to its swelling in fresh water. The average vertical swelling potential of Milton Queenston Shale in water was 0.19 $\%$ strain/log cycle of time, while it was $0.065 \%$ strain $/ \log$ cycle of time in polymers solution, i.e. $66 \%$ suppression of swelling strains in the vertical direction. Similarly, average horizontal 
swelling potential of Milton Queenston Shale in water was $0.156 \%$ strain/log cycle of time, while horizontal swelling potential of Milton Queenston Shale in polymers solution was only $0.027 \%$ strain $/ \log$ cycle of time, i.e., $83 \%$ suppression of swelling strains in the horizontal direction, which suggests that the polymer solution is more effective in suppressing swelling strain of Milton Queenston Shale in the horizontal direction. This finding is consistent with the observation made from scanning electron microscopy images that the generated microcracks in the horizontal sections were relatively smaller than those in the vertical sections. On the other hand, the average vertical swelling potential of Milton Queenston Shale in bentonite solution was $0.235 \%$ strain $/ \log$ cycle of time, which means an increase of $24 \%$ over the average vertical swelling potential in water, and the horizontal swelling potential of Milton Queenston Shale in bentonite solution was $0.17 \%$ strain/log cycle of time, which represents an increase of $10 \%$ over that in water. This impact of bentonite solution on swelling of Milton Queenston Shale has to be considered when adopting this fluid as a lubricant for micro-tunnelling projects in Milton Queenston Shale. The scanning electron microscopy images explain the behaviour of Milton Queenston Shale in the free swell tests in bentonite solution. These images demonstrate that both size and depth of micro-cracks of the Milton Queenston Shale specimen increased after being exposed to the bentonite solution.

The results of the free swell test performed on Niagara Queenston Shale are presented in Table 4 and Figure 7. The presented results revealed that water resulted in the highest swelling potential in both vertical and horizontal directions, in comparison to polymer and bentonite solutions. In the specimens that were collected from borehole 1 (N-FST10 to NFST18), the average vertical swelling potential of Niagara Queenston Shale in water was $0.525 \%$ strain $/ \log$ cycle of time, while it was $0.39 \%$ strain $/ \log$ cycle of time in bentonite 
solution and only $0.053 \%$ strain/log cycle of time in polymer solution, with a reduction of $26 \%$ and $90 \%$, respectively. In the horizontal direction, the average horizontal swelling potential of Niagara Queenston Shale in water was $0.21 \%$ strain/log cycle of time, while it was $0.16 \%$ strain/log cycle of time in the bentonite solution and only $0.043 \%$ strain/log cycle of time in the polymer solution and with a reduction of $24 \%$ and $80 \%$, respectively. These results demonstrated that both polymer and bentonite solutions were efficient in supressing the swelling strains of Niagara Queenston Shale in both vertical and horizontal directions in comparison to the swelling strains in water. However, the polymers solution was superior in suppressing the swelling deformation of Niagara Queenston Shale. For the specimens that were collected from borehole 2 (N-FST1 to N-FST9), the average vertical swelling potential of Niagara Queenston Shale in water was $0.31 \%$ strain/log cycle of time, while it was $0.23 \%$ strain $/ \log$ cycle of time and $0.06 \%$ strain $/ \log$ cycle of time in bentonite and polymer solutions, i.e., reduction of $26 \%$ and $81 \%$, respectively. In addition, the average horizontal swelling potential of Niagara Queenston Shale in water was $0.17 \%$ strain/log cycle of time, while it was $0.163 \%$ strain/log cycle of time and $0.047 \%$ strain/log cycle of time in the bentonite and polymer solutions, i.e., reduction of $45 \%$ and $72 \%$, respectively.

The above results clearly show that the swellings strain of both Milton Queenston Shale and Niagara Queenston Shale in water, polymers, and bentonite solutions are anisotropic, with the vertical strain (i.e. perpendicular to rock bedding) higher than the horizontal strain (i.e. parallel to rock bedding). It can be also concluded that the polymers solution significantly reduced the swelling deformations of both Milton Queenston Shale and Niagara Queenston Shale, while the bentonite solution was less efficient in reducing the swelling strains of Niagara Queenston Shale, and resulted in a slight increase in the deformation strains of 
Milton Queenston Shale. This finding is of significance. The polymer solution can be used as an effective means to reduce and control the swelling strain of Queenston Shale and to mitigate the time-dependent effects of these shales on the micro-tunnelling machine and on the installed pipe.

\section{Semi-Confined Swell Test}

In order to investigate the influence of the applied pressure on the swelling strains of Milton Queenston Shale and Niagara Queenston Shale in water, polymer, and bentonite solutions, the semi-confined swell tests were performed. Each tested specimen was subjected to a constant pressure in one direction, while it was submerged in the solution, and the swelling strain in the same direction of the applied pressure was continuously recorded for 100 days. For Milton Queenston Shale, each test was repeated three times and the average value of the swelling potential for each corresponding applied pressure was calculated. Due to the limited supply of available Niagara Queenston Shale samples, only one specimen from borehole 1 was tested for each corresponding applied pressure in both directions. The results of the semiconfined swell tests are presented in Table 5 to Table 7 and in Figure 9 and Figure 10 for Milton Queenston Shale and Niagara Queenston Shale, respectively. Figures 9 and 10 show that, as expected, the swelling strain of both Milton Queenston Shale and Niagara Queenston Shale in both directions and in all fluids is a function of the applied pressure. As the applied pressure increased, the vertical swelling potential and the horizontal swelling potential decreased gradually from their values in the free swell tests. Moreover, the general trends observed in free swell tests for both Milton and Niagara Queenston Shales are also observed in the semi-confined swell tests: Niagara Queenston Shale exhibited higher vertical swelling potential and horizontal swelling potential than Milton Queenston Shale; the polymers solution significantly reduced the swelling strains in both Milton and Niagara Queenston 
Shales, and the bentonite solution had opposite effects on the swelling strains of Milton Queenston Shale and Niagara Queenston Shale.

Under applied pressure of $0.01 \mathrm{MPa}$, the water resulted in vertical swelling potential of 0.18 $\%$ strain/log cycle of time and horizontal swelling potential of $0.13 \%$ strain $/ \log$ cycle of time in Milton Queenston Shale, while in Niagara Queenston Shale it resulted in vertical swelling potential of $0.515 \%$ strain/log cycle of time and horizontal swelling potential of $0.205 \%$ strain/log cycle of time. Under the same applied pressure of $0.01 \mathrm{MPa}$, the polymers solution reduced vertical swelling potential and horizontal swelling potential of Milton Queenston Shale by $64 \%$ and $85 \%$, respectively, and reduced vertical swelling potential and horizontal swelling potential for Niagara Queenston Shale by $26 \%$, and $80 \%$, respectively. As the applied pressure varied from 0.01 to $0.05,0.1$, and 1.0 MPa in Milton Queenston Shale, the suppression effect of the polymers solution on horizontal swelling potential was more evident and reached $100 \%$ with $0.7 \mathrm{MPa}$, while vertical swelling potential was reduced by $54 \%, 60 \%$ and 25\%, respectively. In Niagara Queenston Shale, the polymers solution reduced horizontal swelling potential by $83 \%$ under applied pressure of $0.3 \mathrm{MPa}$, while it reduced vertical swelling potential by $91 \%$ under applied pressure of $0.1 \mathrm{MPa}$. On the other hand, the bentonite solution increased vertical swelling potential and horizontal swelling potential of Milton Queenston Shale by $22 \%$ and $8 \%$, respectively, while it reduced vertical swelling potential and horizontal swelling potential by $42 \%$ and $24 \%$, respectively, under applied pressure $0.01 \mathrm{MPa}$.

These results clearly show that swelling strains are anisotropic with respect to the rock bedding and they strongly depend on the applied pressure. The polymer solution significantly suppressed the swelling strains of both shales in both orthogonal directions, under variable amounts of applied pressure. The bentonite solution was less efficient in suppressing the 
swelling strains of Niagara Queenston Shale, but increased the swelling strains of Milton Queenston Shale under variable amounts of applied pressure.

\section{Null Swell Test}

The results of the null swell tests performed on Milton Queenston Shale and Niagara Queenston Shale from borehole 1 are presented in Tables 8 and 9, and in Figures 10 and 11, respectively. The shale specimens were prevented from swelling in one direction, while they were submerged in the solution, by adding gradual loads in the same direction, through the apparatus. The tests were terminated when the specimens reached equilibrium stage (i.e. no more load was required to prevent their swelling). The load at that stage divided by the crosssectional area of the specimen is the suppression pressure, which was termed as "the critical stress $\left(\sigma_{c}\right)$ ", by Lo and Hefny (1996).

Figures 10 and 11 show that the average null-swell pressure in water was $2.14 \mathrm{MPa}$, and 2.06 $\mathrm{MPa}$, in the vertical and horizontal directions for Milton Queenston Shale and was 2.07 and 1.59 $\mathrm{MPa}$ for Niagara Queenston Shale. Figures 10 and 11 also show general trends consistent with those observed in the free swell tests and the semi-confined swell tests: the suppression pressures of both Milton Queenston Shale and Niagara Queenston Shale in the polymer solution was the least among other fluids; and bentonite solution had opposite effects on the suppression pressures of Milton Queenston Shale and Niagara Queenston Shale.

In comparison to water, the polymers solution effectively reduced the average null-swell pressure in both Milton Queenston Shale and Niagara Queenston Shale by 30\% and 27\%, and by $28 \%$ and $51 \%$ in the vertical and horizontal directions, respectively. On the other hand, the null-swell pressures of Milton Queenston Shale in bentonite solution were greater than that in 
water, while the opposite was observed for Niagara Queenston Shale. The null swell pressures of Milton Queenston Shale in bentonite solution increased by $10 \%$ and $9 \%$ in the vertical and horizontal compared to water, while for Niagara Queenston Shale they decreased by $13 \%$ and $29 \%$. Finally, it is noted that although the swelling strains of Niagara Queenston Shale were, in general, greater than that in Milton Queenston Shale in both of the free swell tests and the semi-confined swell tests, the average null-swell pressure in Niagara Queenston Shale was less than that in Milton Queenston Shale in all used fluids.

\section{Construction of Swelling Envelopes}

The results of the swelling test program in this research can be summarized in swelling envelopes defined in the model proposed by Lo and Hefny (1996). In this model, the average free swell potentials (vertical swelling potential and horizontal swelling potential), and the average of vertical swelling potential and horizontal swelling potential under different applied pressures are plotted on the y-axis versus the applied pressure in a log scale, on the $\mathrm{x}$ axis. The average null-swell pressures in the vertical and horizontal directions, where the swell was completely suppressed, are also presented in this model. The average values of free swell tests, semi-confined swell tests, and null swell tests are summarized and presented in Table 11. For Milton Queenston Shale, the average was calculated from tests performed on the adopted ambient fluids (i.e. water, $0.8 \%$ polymer solution and $8 \%$ bentonite solution). Other tests performed on variable concentrations of polymer and bentonite solutions were not included in calculating the average. For Niagara Queenston Shale, only test results from borehole 1, where samples were enough to perform the three types of swelling tests were considered in calculating the average. Based on these average values, the swelling envelopes 
of Milton Queenston Shale and Niagara Queenston Shale were constructed in both vertical and horizontal directions, and are presented in Figure 12 and Figure 13, respectively. In these figures, the horizontal lines represent the average swell potentials from the free swell tests, while the inclined lines represent the swell potentials under different values of applied pressure (suppression pressure). The $\mathrm{x}$-intercepts represent the average null swell pressures, defined by Lo and Hefny (1996) as the critical stresses $\left(\sigma_{c}\right)$. The critical stress represents the minimum stress that is required to supress the swelling strain completely in the direction of the applied stress. The intercepts of the horizontal line and the inclined line represents the threshold stress $(\sigma$ th $)$, as defined in the aforementioned model. The threshold stress represents the minimum required stress to be applied on the rock to initiate the suppression influence on the swelling deformation in the same direction of the applied stress. The stresses that lie between the threshold stress and the critical stress represent the required stresses for partial suppression of the swelling deformation of the tested rock.

The swelling envelopes of Milton Queenston Shale and Niagara Queenston Shale displayed in Figures 12 and 13 demonstrate that the polymer and bentonite solutions can have a significant influence on the swelling behaviour of these shales in comparison to their swelling behaviour in water. As part of the design process of buried structures in swelling rocks, such as Milton Queenston Shale and Niagara Queenston Shale, water is usually used as the only ambient fluid in the experimental program to develop the swelling envelopes of these rocks, and to derive the consequent design parameters. The findings of the current study clearly show that using fluid other than water, can significantly change the shape of the swelling envelopes, and hence change the derived design parameters. The polymer solution effectively suppressed the swelling strains of both Milton Queenston Shale and Niagara Queenston Shale, and thus significantly reduced the swelling envelopes of both shales. The bentonite solution was less effective than polymer solution in suppressing the swelling strains of 
Niagara Queenston Shale, while it had negatively increased the swelling strains of Milton Queenston Shale. In general, it can be noted that the variation in the threshold stresses for the three used fluids in the horizontal swelling envelopes was smaller than the variation in the threshold stresses of the vertical envelopes. This means that Milton Queenston Shale and Niagara Queenston Shale are more susceptible to the type of fluids in the vertical direction than in the horizontal direction under different applied supressing stresses.

\section{Summary and Conclusions}

A comprehensive testing program was performed on Queenston shale from Milton and Niagara regions in Southern Ontario to investigate the influence of lubricant fluids, such as polymers and bentonite solutions that used in micro-tunnelling process, on the swelling behaviour of these shales. Water, which is the standard ambient fluid for swell tests was also used in these tests for comparison purposes with the lubricant fluids. The testing program was performed utilizing the free swell test, semi-confined swell test, and the uniaxial null-swell test, that were developed in Western University by Lo and co-workers (1978-1999). In the testing program, 48 free swell tests, 72 semi-confined swell tests, and 24 null-swell tests, in addition to complementary tests were performed on both of the tested shales. In order to obtain the swelling parameters of Queenston Shale in lubricant fluids used in microtunnelling process, the standard ambient fluid used in swelling tests (i.e. water) was replaced with lubricant fluids (i.e. polymer and bentonite solutions) in this research. Swelling parameters (i.e. vertical and horizontal swelling potential, threshold pressure, and critical pressure) in lubricant fluids and in water were derived accordingly. The suggested mechanism of lubricant fluids on the swelling behaviour of Queenston Shale can be summarized as follows: Both polymer solution and bentonite solution create coating layers on 
the outer surface of rock and reduce osmoses water molecules penetration deep into the rock. However the thickness of these layers is different. Polymers tend to penetrate deeper into the surface micro-cracks and tend to accumulate in a thicker layer compared to bentonite. This makes polymer solution more efficient than bentonite in preventing more water molecules penetration, and hence caused less swelling of Queenston Shale.

The swelling envelopes in the vertical and horizontal directions for both Milton Queenston Shale and Niagara Queenston Shale were developed. From the results of the performed testing program, the following conclusions can be drawn:

1) The lubricant fluids used in micro-tunnelling process, such as polymer and bentonite solutions can cause a considerable influence on the swelling behaviour of Milton Queenston Shale and Niagara Queenston Shale.

2) In comparison to water, the polymer solution effectively reduced the swelling strains of both Milton and Niagara Queenston Shales in both vertical and horizontal directions, with greater effect in the horizontal direction. The percentage of reduction in the swelling strains could be as high as $90 \%$.

3) The bentonite solution was less efficient than polymer solution in reducing the swelling strains of Niagara Queenston Shale by $24-26 \%$ in comparison to water, and it caused an increase in the swelling strains of Milton Queenston Shale by 10-24\%.

4) The swelling behaviour of Milton Queenston Shale and Niagara Queenston Shale in the lubricant fluids as in the case of in water is anisotropic with respect to the rock bedding, with the swelling strain in the vertical direction, in general, higher than in the horizontal direction.

5) The reverse influence of bentonite solution on the swelling strain of Milton Queenston Shale and Niagara Queenston Shale may be attributed to the movement of cations 
from the shale to the bentonite solution and vice versa. However, more detailed investigation has to be performed.

6) The stress-dependent behaviour of both Milton Queenston Shale and Niagara Queenston Shale in lubricant fluids can be represented by the Lo and Hefny (1996) model.

It appears that the swelling behaviour of swelling rocks in the lubricant fluids, can be significantly different from their behaviour in water, and therefore it is recommended to extend this research to include more types of swelling rocks.

\section{Acknowledgements}

The work presented in this paper forms part of a research program to investigate the practical problems associated to micro-tunnelling process in Queenston shale of Southern Ontario, being undertaken at the Geotechnical Research Centre in Western University, Canada. The authors are very grateful to Ward and Burke Microtunnelling Ltd. for their financial contribution to support this research, and for collecting the rock samples from Milton, Ontario. 


\section{References}

ASTM. 2013. Standard Test Method for Measurement of Rate of Absorption of Water by Hydraulic-Cement Concretes. ASTM standard C1585-13. West Conshohocken, Pa.

ASTM 2010. Standard Test Methods for Laboratory Determination of Water (Moisture) Content of Soil and Rock by Mass. ASTM standard D2216-10. ASTM International, West Conshohocken, Pa.

ASTM. 2008. Standard practices for preparing rock core as cylindrical test specimens and verifying conformance to dimensional and shape tolerances. ASTM standard D454308. ASTM International, West Conshohocken, Pa.

Al-Maamori, H.M.S., El Naggar, M.H., and Silvana, M. 2014. A Compilation of the GeoMechanical Properties of Rocks in Southern Ontario and the Neighbouring Regions. Open Journal of Geology, 4, 210-227. doi: org/10.4236/ojg.2014.45017

Bowen, C.F.P., Hewson, F.I., MacDonald, D.H. and Tanner, R.G. 1976. Rock squeeze at Thorold Tunnel. Canadian Geotechnical Journal, 13(2): 111-126. doi: 10.1139/t76-013.

Dreimanis, A. 1962. Quantitative Gasometric Determination of Calcite and Dolomite By Using Chittick Apparatus. Journal of Sedimentary Petrology, 32(3): 520 - 529.

Evangelou, V.P. 1998. Environmental Soil And Water Chemistry: Principles And Applications. John Wiley \&Sons, Inc., Toronto.

Einstein, H.H. and Bischoff, N. 1975. Design of tunnels in swelling rocks. Proceedings of the $16^{\text {th }}$ Symposium on Rock Mechanics, University of Minnesota, Minneapolis, MN, PP. $185-197$. 
Huang, J.A. 1993. Long-term deformation behaviour of Queenston Shale. M.E.Sc. Thesis, Western University, London, Ontario.

Hein, F.J. and Longstaffe, F.J. 1983. Geotechnical, sedimentological and mineralogical investigations in Arctic Fjords. In: J.P.M. Syvitski and C.P, Blakeney (Compilers), Sedimentology of Arctic Fjords Experiment: HU 82-031m Data Report I. Can. Data Rep. Hydrogr. Ocean Sci. 12, pp.11-1-11-158.

Hefny, A., Lo, K.Y. and Huang, J.A. 1996. Modelling of long-term time-dependent deformation and stress-dependency of Queenston shale. Canadian Tunnelling 1996, The Tunnelling Association of Canada, pp. 115-146.

Lee, Y.N. 1988. Stress-strain-time relationship of Queenston shale. Ph.D. thesis, Civil and Environmental Engineering Department, The University of Western Ontario, London, ON.

Lee, Y.N. and Lo, K.Y. 1993. The swelling mechanism of Queenston shale. Canadian Tunnelling 1993, The Tunnelling Association of Canada, pp. 75-97.

Lo, K.Y. 1978. Regional distribution of in situ horizontal stresses in rocks of Southern Ontario. Canadian Geotechnical Journal, 15(3): 371-381.

doi:10.1139/t78-034

Lo, K.Y. and Hefny, A.M. 1999. Measurements of Residual Expansion Rates Resulting from Alkali-Aggregate Reaction in Existing Concrete Dams. ACI Materials Journal, 96(3): $339-345$. 
Lo, K.Y. and Hefny, A.1996. Design of tunnels in rock with long-term time-dependent and nonlinearly stress-dependent deformation. Canadian Tunnelling 1996, The Tunnelling Association of Canada, Toronto, Ontario, pp. 179-214.

Lo, K.Y. and Lee, Y.N. 1990. Time-dependent deformation behaviour of Queenston shale. Canadian Geotechnical Journal, 27(4): 461-471. doi: 10.1139/t90-061.

Lo, K.Y. And Yuen, C.M.K. 1981. Design of tunnel lining in rock for long term time effects. Canadian Geotechnical Journal, 18(1): 24-39. doi: 10.1139/t81-004.

Lo, K.Y., Cooke, B.H., and Dunbar, D.D. 1987. Design of buried structures in squeezing rock in Toronto, Canada. Canadian Geotechnical Journal, 24(2): 232-241. doi: 10.1139/t87-028.

Lo, K.Y., Lee, C.F., Palmer, J.H.L. and Quigley, R.M. 1975. Stress relief and timedependent deformation of rocks. Final Report, National Research Council of Canada Special Project No. 7303, Faculty of Engineering Science, The University of Western Ontario, London, ON.

Lo, K.Y., Wai, R.S.C., Palmer, J.H.L. and Quigley, R.M. 1978. Time-dependent deformation of shaly rocks in Southern Ontario. Canadian Geotechnical Journal, 15(4): 537-547. doi: $10.1139 / \mathrm{t} 78-057$

McBride, M.B. 1994. Environmental Chemistry of Soils. Oxford University Press, Inc., 200 Madison Avenue, New York.

Morison, W.G. 1957. Rock squeeze investigation. Ontario Hydro Research Division Report No.57-13, Toronto Power Generating Station, Ontario Hydro Research Division, Toronto, Ontario. 
Moore, D.M. and Reynolds, R.C., Jr. 1989. X-Ray Diffraction and the Identification and Analysis of Clay Minerals. Oxford University Press, Oxford, New York.

Wai, R.S.C. 1977. Time-dependent deformation of some shaly rocks. M.E.Sc. thesis, The University of Western Ontario, London, Ontario.

Zhang, G., Germaine, J.T., Martin, R. T., and Whittle, A.J. 2003. A Simple Sample-Mounting Method for Random Powder. Clays and Clay Minerals, 51(2): 218-225. 
Table 1. Percentage Minerals of Milton and Niagara Queenston Shales from X-Ray Diffraction Analyses

\begin{tabular}{|c|c|c|c|c|c|c|c|c|}
\hline \multicolumn{9}{|l|}{ Milton Queenston Shale } \\
\hline Sample Depth (m) & Chlorite (\%) & Illite (\%) & Kaolinite (\%) & Quartz (\%) & Feldspar (\%) & Calcite (\%) & Dolomite (\%) & Pyrite (\%) \\
\hline 16.57 & 0.8 & 16.5 & 2.4 & 45.5 & 4.7 & $20.9 / 25.1 *$ & $6.2 / 2.8^{*}$ & 3.0 \\
\hline 21.16 & 0.6 & 11.8 & 1.1 & 47.4 & 3.3 & $28.2 / 21.9^{*}$ & $3.9 / 3.0^{*}$ & 3.7 \\
\hline 25.14 & 1.0 & 16.8 & 1.7 & 43.1 & 5.9 & $19.3 / 21.4^{*}$ & $9.2 / 2.9^{*}$ & 3.0 \\
\hline 31.04 & 1.1 & 10.4 & 1.3 & 47.4 & 6.7 & $24.9 / 24.1^{*}$ & $6 / 7.9^{*}$ & 2.2 \\
\hline Percentage Range & $0.8-1.1$ & $10.4-16.8$ & $1.1-2.4$ & $43.1-47.4$ & $3.3-6.7$ & $19.3-28.2$ & $3.9-9.2$ & $2.2-3.7$ \\
\hline \multicolumn{9}{|l|}{ Niagara Queenston Shale } \\
\hline Sample Depth (m) & Chlorite (\%) & Illite $\quad(\%)$ & Kaolinite (\%) & Quartz (\%) & Feldspar (\%) & Calcite $(\%)$ & Dolomite (\%) & Pyrite (\%) \\
\hline 6.1 & 1.6 & 23.0 & 1.8 & 56.7 & 2.8 & $8.1 / 8.9^{*}$ & $2.4 / 2.3^{*}$ & 3.6 \\
\hline 11.2 & 1.4 & 16.3 & 1.9 & 59.7 & 5.5 & $9.4 / 9.5^{*}$ & $3.2 / 2.3^{*}$ & 2.6 \\
\hline Percentage Range & $1.4-1.6$ & $16.3-23.0$ & $1.8-1.9$ & $56.7-59.7$ & $2.8-5.5$ & $8.1-9.4$ & $2.4-3.2$ & $2.6-3.6$ \\
\hline
\end{tabular}


Table 2. Cation Exchange Capacity of Milton and Niagara Queenston Shales and Bentonite Solution

\begin{tabular}{|c|c|c|c|c|c|c|c|c|c|c|}
\hline \multirow{2}{*}{ Cation Exchange Capacity (CEC) In (meq/100 g) } & \multicolumn{2}{|c|}{$\mathrm{CEC} \mathrm{Ca}^{2+}$} & \multicolumn{2}{|c|}{$\mathrm{CEC} \mathrm{K}^{+}$} & \multicolumn{2}{|c|}{$\mathrm{CEC} \mathrm{Mg}^{2+}$} & \multicolumn{2}{|c|}{$\mathrm{CEC} \mathrm{Na}^{+}$} & \multicolumn{2}{|c|}{ CEC Total } \\
\hline & Before & After & Before & After & Before & After & Before & After & Before & After \\
\hline Niagara Queenston Shale (NQS) & 30.5 & 31.275 & 2.3 & 2.12 & 1.745 & 1.39 & 10.585 & 3.515 & 45.13 & 38.3 \\
\hline Milton Queenston Shale (MQS) & 31.98 & 33.185 & 1.89 & 1.92 & 1.965 & 1.72 & 1.725 & 4.685 & 37.56 & 41.51 \\
\hline Fresh Bentonite Solution & 2.83 & - & 0.2 & - & 0.585 & - & 6.765 & - & 10.38 & - \\
\hline Bentonite Solution After NQS Test & - & 4.84 & - & 0.22 & - & 0.97 & - & 5.97 & - & 12 \\
\hline Bentonite Solution After MQS Test & - & 4.11 & - & 0.15 & - & 0.85 & - & 5.15 & - & 10.26 \\
\hline
\end{tabular}


Table 3. Free Swell Test and Complementary Tests Results of Milton Queenston Shale

\begin{tabular}{|c|c|c|c|c|c|c|c|c|c|c|c|c|}
\hline $\begin{array}{l}\text { Specimen } \\
\text { No. }\end{array}$ & Ambient Fluid & Depth $(\mathrm{m})$ & $\begin{array}{c}\text { Calcite } \\
\text { Content } \\
(\%)\end{array}$ & $\begin{array}{c}\text { Dolomite } \\
\text { Content } \\
(\%)\end{array}$ & $\begin{array}{c}\text { Moisture } \\
\text { Content } \\
\text { Before } \\
\text { Test (\%) }\end{array}$ & $\begin{array}{c}\text { Moisture } \\
\text { Content } \\
\text { After Test } \\
(\%)\end{array}$ & $\begin{array}{c}\text { Pore } \\
\text { Salinity } \\
\text { Before } \\
\text { Test } \\
(\mathrm{g} / \mathrm{L})\end{array}$ & $\begin{array}{c}\text { Pore } \\
\text { Salinity } \\
\text { After Test } \\
\text { (g/L }\end{array}$ & $\begin{array}{c}\text { Percent } \\
\text { Decrease } \\
\text { In Pore } \\
\text { Salinity } \\
(\%)\end{array}$ & $\begin{array}{c}\text { Mass } \\
\text { Density } \\
(\mathrm{g} / \mathrm{cm} 3)\end{array}$ & $\begin{array}{c}\text { Horizontal } \\
\text { Swelling } \\
\text { Potential } \% \\
\text { strain/ log } \\
\text { cycle of } \\
\text { time) }\end{array}$ & $\begin{array}{l}\text { Vertical } \\
\text { Swelling } \\
\text { Potential } \\
\text { (\% strain } \\
\text { log cycle } \\
\text { of time) }\end{array}$ \\
\hline M-FST 4 & Air & 20.40 & 22.5 & 2.3 & 2.00 & 2.31 & 75.0 & - & - & 2.601 & 0.04 & 0.025 \\
\hline M-FST 16 & Water & 20.63 & 22.8 & 2.1 & 2.92 & 3.58 & 73.7 & 21.9 & 70 & 2.629 & 0.16 & 0.2 \\
\hline M-FST 21 & Water & 20.75 & 16.5 & 2.5 & 2.00 & 2.67 & 75.0 & 28.0 & 63 & 2.623 & 0.145 & 0.18 \\
\hline M-FST 22 & Water & 30.02 & 15 & 3.9 & 2.84 & 3.51 & 149.7 & 76.2 & 49 & 2.623 & 0.21 & 0.24 \\
\hline M-FST 25 & Water & 26.31 & 30.3 & 1.8 & 19.30 & 3.73 & 81.7 & 42.2 & 48 & 2.633 & 0.155 & 0.21 \\
\hline M-FST 27 & Water & 26.59 & 30.3 & 1.8 & 2.55 & 3.20 & 93.1 & 46.6 & 50 & 2.626 & 0.11 & 0.12 \\
\hline M-FST 1 & $1 \%$ bentonite $\& 0.1 \%$ polymers & 15.98 & 24.3 & 0.7 & 2.91 & 3.41 & 86.0 & 40.3 & 53 & 2.405 & $0.1 *$ & $0.14 *$ \\
\hline M-FST 2 & $1 \%$ bentonite \& $0.2 \%$ polymers & 16.15 & 22.8 & 2.1 & 2.10 & 2.39 & 95.2 & 39.4 & 59 & 2.616 & $0.07 *$ & $0.08 *$ \\
\hline M-FST 3 & $1 \%$ bentonite \& $0.3 \%$ polymers & 16.31 & 23.0 & 1.8 & 2.05 & 2.38 & 73.2 & 0.1 & 100 & 2.617 & $0.09 *$ & $0.1 *$ \\
\hline M-FST 5 & 2.4\% Bentonite Solution & 17.83 & 22.8 & 2.1 & 2.70 & 3.39 & 83.3 & 25.3 & 70 & 2.656 & $0.03 *$ & $0.02 *$ \\
\hline M-FST 6 & $2.8 \%$ Bentonite Solution & 17.81 & 23.3 & 1.6 & 2.50 & 3.22 & 100.0 & 25.7 & 74 & 2.648 & 0.07 * & $0.1 *$ \\
\hline M-FST 7 & 3.6\% Bentonite Solution & 18.24 & 23.0 & 1.8 & 2.56 & 3.32 & 97.7 & 26.0 & 73 & 2.657 & $0.08 *$ & $0.19 *$ \\
\hline M-FST 8 & $3.2 \%$ Bentonite Solution & 18.75 & 23.5 & 1.4 & 3.00 & 3.68 & 83.4 & 24.5 & 71 & 2.559 & $0.075 *$ & $0.125 *$ \\
\hline M-FST 9 & 4. $0 \%$ Bentonite Solution & 19.96 & 23.8 & 1.1 & 2.60 & 3.29 & 96.0 & 29.5 & 69 & 2.608 & $0.085 *$ & $0.195 *$ \\
\hline M-FST 15 & $3.6 \%$ Bentonite Solution & 20.60 & 23.5 & 1.4 & 2.11 & 2.31 & 95.0 & 28.9 & 70 & 2.637 & $0.08 *$ & $0.15 *$ \\
\hline M-FST 24 & $8 \%$ Bentonite Solution & 30.71 & 12.1 & 2.3 & 3.13 & 3.82 & 145.9 & 20.4 & 86 & 2.636 & 0.2 & 0.226 \\
\hline M-FST 28 & $8 \%$ Bentonite Solution & 26.70 & 29.4 & 1.8 & 2.50 & 3.38 & 148.6 & 34.8 & 77 & 2.632 & 0.13 & 0.24 \\
\hline M-FST 29 & $8 \%$ Bentonite Solution & 26.62 & 29.3 & 3.2 & 2.20 & 2.89 & 118.3 & 25.6 & 78 & 2.631 & 0.18 & 0.24 \\
\hline M-FST 10 & $0.2 \%$ Polymers Solution & 19.94 & 22.3 & 2.5 & 2.10 & 2.37 & 71.4 & 48.1 & 33 & 2.647 & $0.12 *$ & 0.125 * \\
\hline M-FST 11 & $0.4 \%$ Polymers Solution & 20.02 & 23.8 & 1.1 & 2.10 & 2.40 & 73.8 & 49.9 & 32 & 2.637 & 0.1 * & $0.11 *$ \\
\hline M-FST 12 & $0.6 \%$ Polymers Solution & 20.09 & 24.1 & 0.9 & 2.77 & 3.20 & 74.0 & 49.0 & 34 & 2.644 & $0.065 *$ & $0.105 *$ \\
\hline M-FST 17 & $0.6 \%$ Polymers Solution & 19.30 & 18.1 & 2.1 & 2.14 & 2.57 & 72.6 & 50.4 & 31 & 2.613 & $0.024 *$ & $0.12 *$ \\
\hline M-FST 13 & $1 \%$ Polymers Solution & 20.17 & 23.8 & 1.1 & 2.10 & 2.40 & 71.4 & 52.0 & 27 & 2.672 & $0.05 *$ & $0.06 *$ \\
\hline M-FST 19 & $1.0 \%$ Polymers Solution & 20.50 & 17.9 & 2.5 & 2.05 & 2.48 & 73.3 & 56.9 & 22 & 2.632 & $-0.002 *$ & $-0.002 *$ \\
\hline M-FST 20 & $1.2 \%$ Polymers Solution & 20.70 & 17.9 & 2.5 & 1.99 & 2.43 & 77.8 & 63.2 & 19 & 2.62 & $0.02 *$ & $-0.03 *$ \\
\hline M-FST 14 & $0.8 \%$ Polymers Solution & 20.32 & 24.3 & 0.7 & 3.02 & 3.64 & 74.5 & 47.5 & 36 & 2.646 & 0.06 & 0.1 \\
\hline M-FST 18 & $0.8 \%$ Polymers Solution & 20.37 & 18.4 & 1.8 & 2.14 & 2.57 & 70.2 & 50.5 & 28 & 2.625 & 0.01 & 0.08 \\
\hline M- FST 23 & $0.8 \%$ Polymers Solution & 30.58 & 13.4 & 3.3 & 2.30 & 2.96 & 173.4 & 119.2 & 31 & 2.63 & 0.053 & 0.095 \\
\hline M-FST 26 & $0.8 \%$ Polymers Solution & 26.43 & 28.6 & 3.8 & 3.65 & 4.09 & 232.9 & 173.0 & 26 & 2.641 & 0.01 & 0.02 \\
\hline M-FST 30 & $0.8 \%$ Polymers Solution & 26.85 & 29.3 & 3.2 & 2.40 & 2.84 & 107.7 & 76.2 & 29 & 2.654 & 0 & 0.030 \\
\hline
\end{tabular}


Table 4. Free Swell Test and Complementary Tests Results of Niagara Queenston Shale

\begin{tabular}{|c|c|c|c|c|c|c|c|c|c|c|c|c|}
\hline $\begin{array}{l}\text { Specimen } \\
\text { No. }\end{array}$ & Ambient Fluid & Depth (m) & $\begin{array}{c}\text { Calcite } \\
\text { Content } \\
(\%)\end{array}$ & $\begin{array}{c}\text { Dolomite } \\
\text { Content } \\
(\%)\end{array}$ & $\begin{array}{l}\text { Moisture } \\
\text { Content } \\
\text { Before } \\
\text { Test }(\%)\end{array}$ & $\begin{array}{l}\text { Moisture } \\
\text { Content } \\
\text { After Test } \\
(\%)\end{array}$ & $\begin{array}{c}\text { Pore } \\
\text { Salinity } \\
\text { Before } \\
\text { Test } \\
(\mathrm{g} / \mathrm{L})\end{array}$ & $\begin{array}{c}\text { Pore } \\
\text { Salinity } \\
\text { Affer Test } \\
\text { (g/L }\end{array}$ & $\begin{array}{c}\text { Percent } \\
\text { Decrease } \\
\text { In Pore } \\
\text { Salinity } \\
(\%)\end{array}$ & $\begin{array}{l}\text { Mass } \\
\text { Density } \\
(\mathrm{g} / \mathrm{cm} 3)\end{array}$ & $\begin{array}{c}\text { Horizontal } \\
\text { Swelling } \\
\text { Potential (\% } \\
\text { strain/ } \log \\
\text { cycle of } \\
\text { time) }\end{array}$ & $\begin{array}{l}\text { Vertical } \\
\text { Swelling } \\
\text { Potential } \\
\text { (\% strain/ } \\
\text { log cycle } \\
\text { of time) }\end{array}$ \\
\hline N-FST 1 & Water & 11.20 & 9.5 & 2.3 & 1.50 & 2.71 & 314.8 & 110.8 & 65 & 2.815 & $0.19 *$ & $0.32 *$ \\
\hline N-FST 5 & Water & 11.66 & 7.6 & 5.0 & 1.10 & 2.31 & 423.9 & 115.6 & 73 & 2.240 & $0.2 *$ & $0.31 *$ \\
\hline N-FST 7 & Water & 9.25 & 7.7 & 4.9 & 1.41 & 2.62 & 379.4 & 109.5 & 71 & 2.689 & $0.12 *$ & $0.3 *$ \\
\hline N-FST 11 & Water & 6.20 & 8.7 & 4.0 & 1.18 & 2.39 & 377.5 & 114.5 & 70 & 2.682 & 0.21 & 0.6 \\
\hline N-FST 15 & Water & 6.55 & 8.4 & 4.3 & 1.16 & 2.37 & 375.9 & 118.3 & 69 & 2.686 & 0.26 & 0.575 \\
\hline N-FST 16 & Water & 6.65 & 7.8 & 4.8 & 0.95 & 2.16 & 394.7 & 120.5 & 69 & 2.675 & 0.16 & 0.4 \\
\hline N-FST 3 & $8 \%$ Bentonite Solution & 11.54 & 8.2 & 4.5 & 1.07 & 2.28 & 434.5 & 208.1 & 52 & 2.691 & $0.16 *$ & 0.21 * \\
\hline N-FST 6 & $8 \%$ Bentonite Solution & 9.18 & 8.3 & 4.3 & 1.27 & 2.48 & 370.1 & 183.6 & 50 & 2.676 & $0.19 *$ & $0.2 *$ \\
\hline N-FST 8 & $8 \%$ Bentonite Solution & 9.31 & 7.9 & 4.8 & 1.03 & 2.24 & 362.7 & 180.2 & 50 & 2.684 & $0.14 *$ & $0.28 *$ \\
\hline N-FST 13 & $8 \%$ Bentonite Solution & 6.40 & 8.5 & 4.1 & 1.44 & 2.65 & 369.8 & 188.2 & 49 & 2.697 & 0.16 & 0.38 \\
\hline N-FST 17 & $8 \%$ Bentonite Solution & 6.70 & 7.7 & 4.9 & 0.92 & 2.13 & 379.1 & 184.3 & 51 & 2.785 & 0.16 & 0.4 \\
\hline N-FST 18 & $8 \%$ Bentonite Solution & 6.80 & 7.8 & 4.8 & 1.20 & 2.20 & 370.8 & 178.5 & 52 & 2.781 & 0.16 & 0.39 \\
\hline N-FST 2 & $0.8 \%$ Polymers Solution & 11.47 & 7.9 & 4.7 & 1.07 & 2.17 & 435.7 & 323.6 & 26 & 2.708 & $0.04 *$ & $0.02 *$ \\
\hline N-FST 4 & $0.8 \%$ Polymers Solution & 11.60 & 7.4 & 5.1 & 1.07 & 2.17 & 435.3 & 341.3 & 22 & 2.706 & $0.04 *$ & $0.08 *$ \\
\hline N-FST 9 & $0.8 \%$ Polymers Solution & 9.38 & 8.0 & 4.6 & 1.13 & 2.34 & 414.8 & 316.7 & 24 & 2.695 & $0.06 *$ & $0.08 *$ \\
\hline N-FST 10 & $0.8 \%$ Polymers Solution & 6.10 & 8.4 & 4.2 & 1.33 & 2.54 & 375.9 & 320.0 & 15 & 2.682 & 0.01 & 0.05 \\
\hline N-FST 12 & $0.8 \%$ Polymers Solution & 6.30 & 8.9 & 3.8 & 0.94 & 2.04 & 397.1 & 311.3 & 22 & 2.688 & 0.06 & 0.07 \\
\hline N-FST 14 & $0.8 \%$ Polymers Solution & 6.50 & 8.2 & 4.4 & 1.44 & 2.54 & 369.8 & 277.9 & 25 & 2.695 & 0.06 & 0.04 \\
\hline
\end{tabular}

Note: * value not included in calculating the average, (samples from borehole2) 
Table 5.Semi-Confined Swell Test in Vertical Direction, and Complementary Tests Results of Milton Queenston Shale

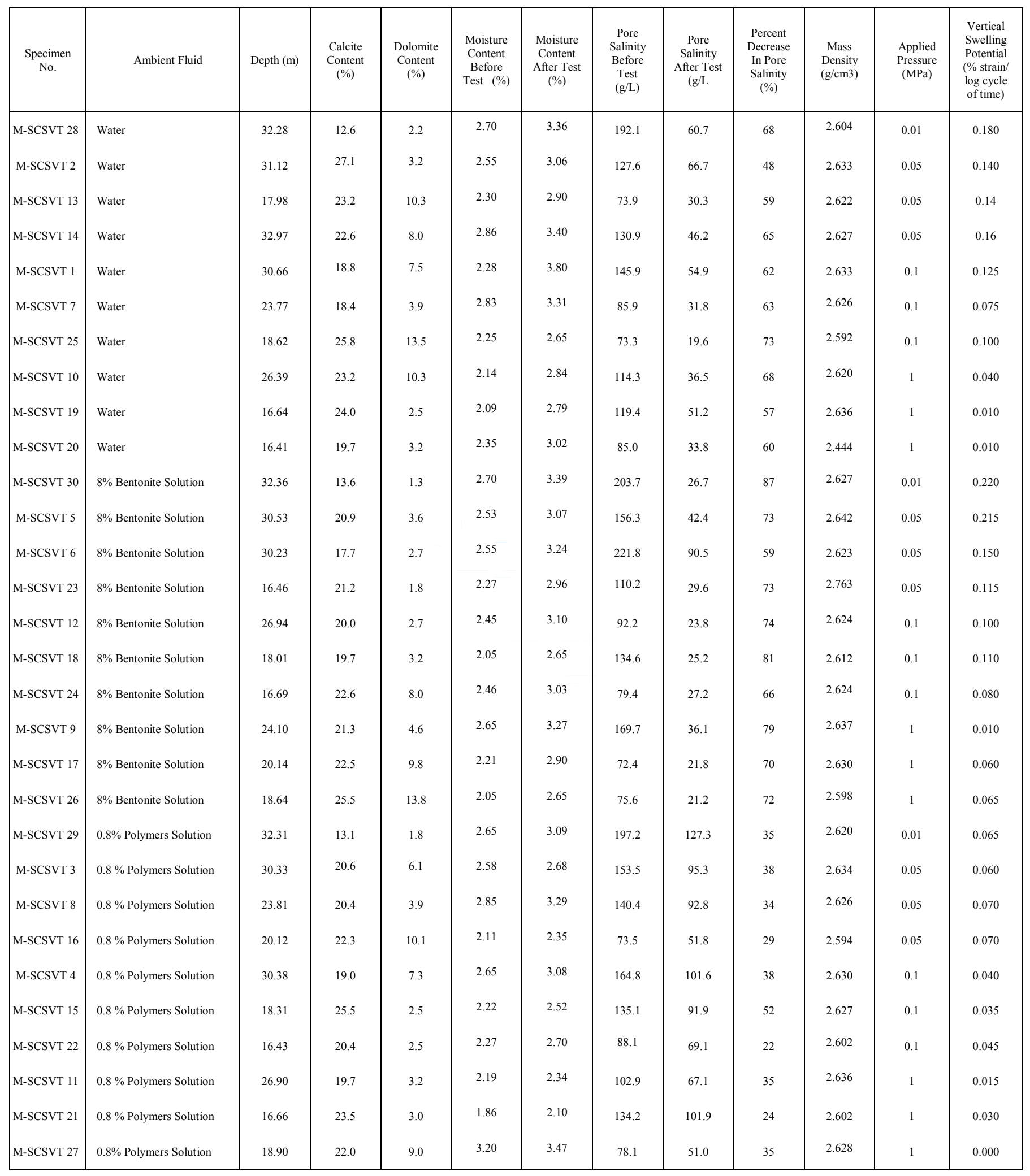


Table 6.Semi-Confined Swell Test in Horizontal Direction, and Complementary Tests Results of Milton Queenston Shale

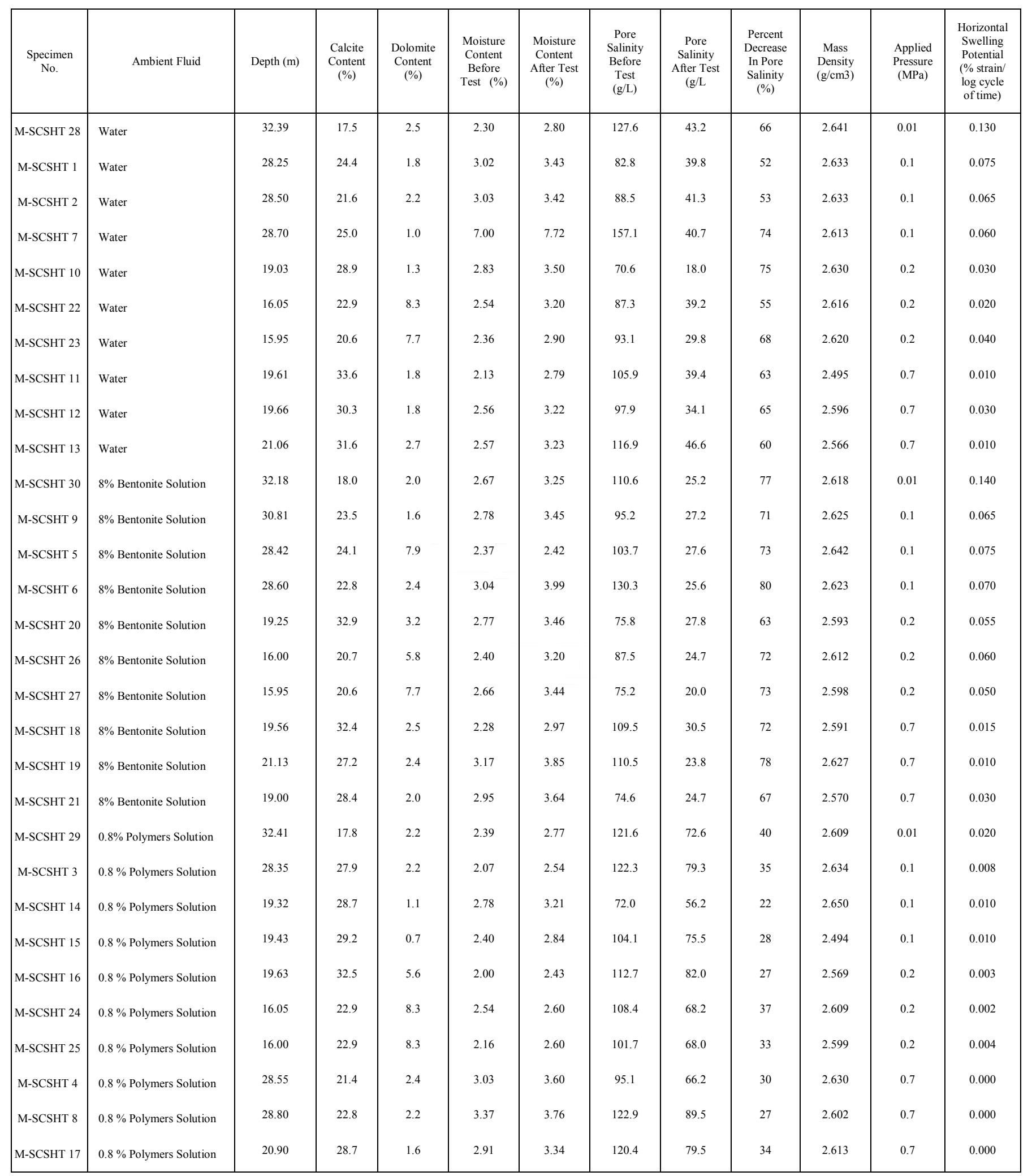


Table 7. Semi-Confined Swell Test in Vertical and Horizontal Directions and Complementary Tests Results of Niagara Queenston Shale

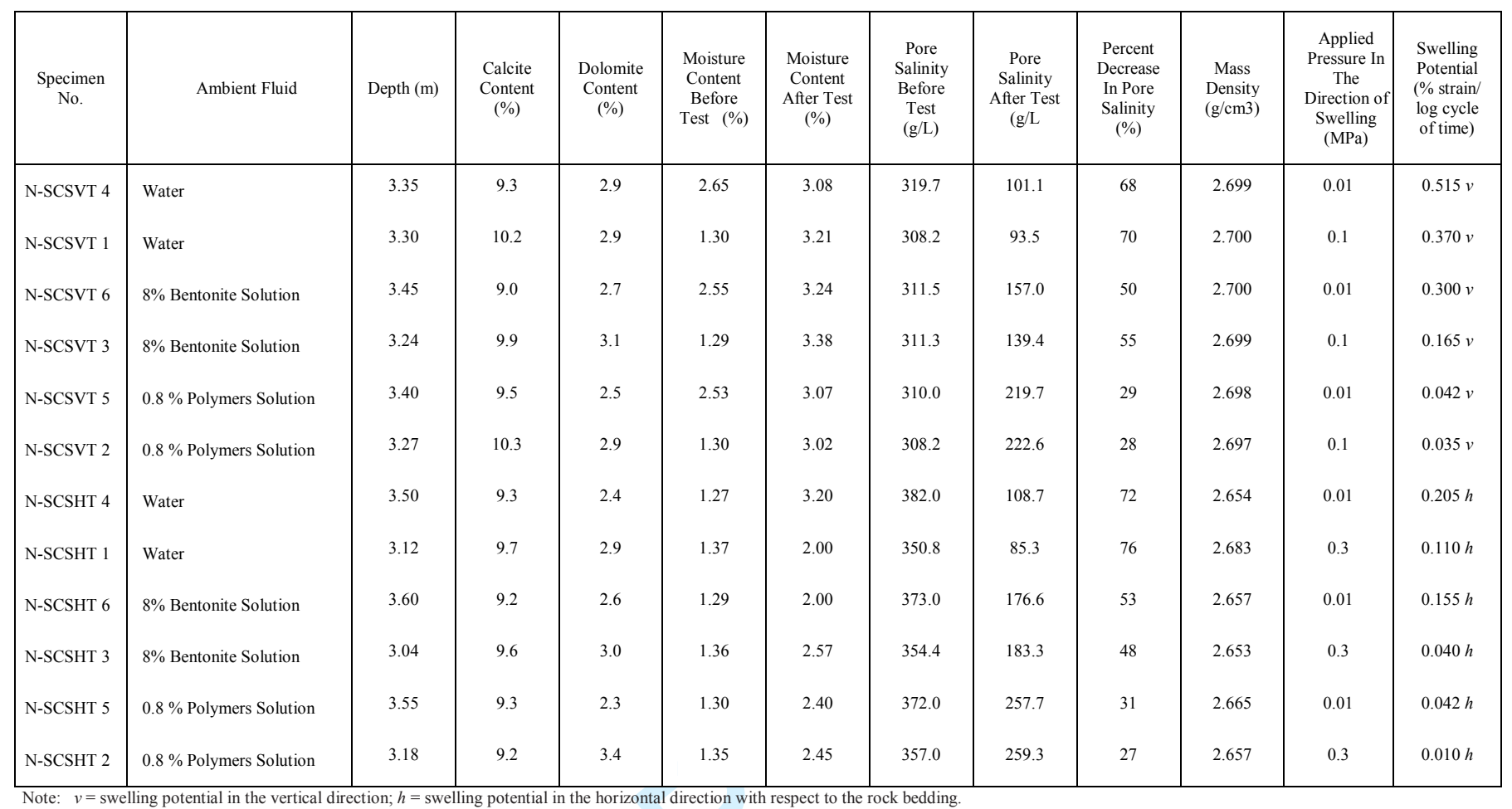


Table 8. Null- Swell Test in Vertical and Horizontal Directions, and Complementary Tests Results of Milton Queenston Shale

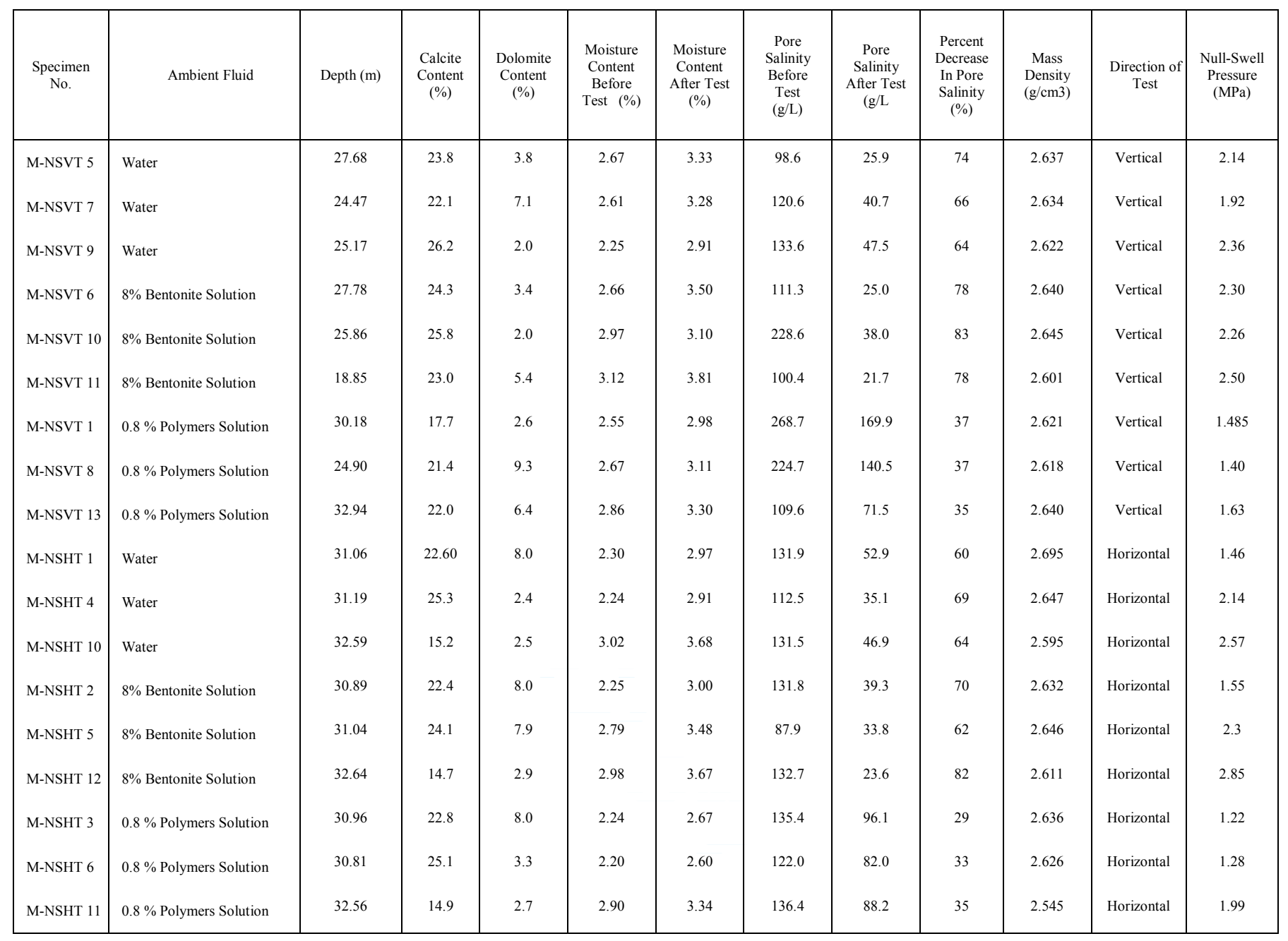


Table 9. Null- Swell Test in Vertical and Horizontal Directions, and Complementary Tests Results of Niagara Queenston Shale

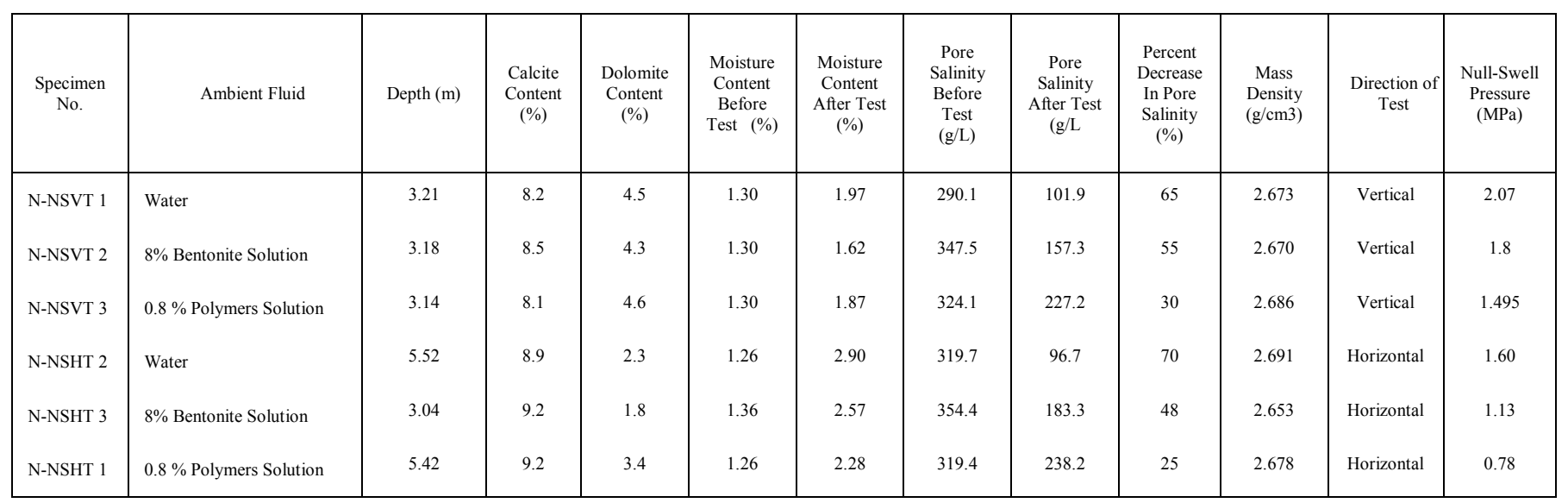


Table 10. Rate of Absorption of Water of Niagara and Milton Queenston Shales in Ambient Fluids

\begin{tabular}{|c|c|c|c|c|c|c|}
\hline \multirow{2}{*}{ Ambient Fluid } & \multicolumn{2}{|c|}{ Rate of Absorption In Water } & \multicolumn{2}{|c|}{ Rate of Absorption In Polymers Solution } & \multicolumn{2}{|c|}{ Rate of Absorption In Bentonite Solution } \\
\hline & Initial, $\mathrm{Si}\left(\mathrm{mm} / \mathrm{V}_{\mathrm{s}}\right)$ & Secondary, Ss $\left(\mathrm{mm} / \mathrm{J}_{\mathrm{s}}\right)$ & Initial, $\mathrm{Si}\left(\mathrm{mm} / \sqrt{\mathrm{s}}_{\mathrm{s}}\right.$ & Secondary, $\mathrm{Ss}\left(\mathrm{mm} / \mathrm{Js}_{\mathrm{s}}\right)$ & Initial, $\mathrm{Si}\left(\mathrm{mm} / \downarrow_{\mathrm{s}}\right)$ & Secondary, Ss $(\mathrm{mm} / \sqrt{\mathrm{s}})$ \\
\hline Niagara Queenston Shale (NQS) & 0.0058 & 0.0011 & 0.0003 & 0.0005 & 0.0003 & 0.0008 \\
\hline Milton Queenston Shale (MQS) & 0.0011 & 0.001 & 0.0005 & 0.0004 & 0.0012 & 0.0011 \\
\hline
\end{tabular}


Table 11. Summary Results of Free Swell Tests, Semi-Confined Swell Tests, and Null Swell Tests Performed on Milton Queenston Shale and Niagara

\begin{tabular}{|c|c|c|c|c|c|c|c|c|c|c|c|c|}
\hline Ambient Fluid & \multicolumn{4}{|l|}{ Water } & \multicolumn{4}{|c|}{$0.8 \%$ Polymer Solution } & \multicolumn{4}{|c|}{$8 \%$ Bentonite Solution } \\
\hline Direction of Test & \multicolumn{2}{|l|}{ Vertical } & \multicolumn{2}{|c|}{ Horizontal } & \multicolumn{2}{|l|}{ Vertical } & \multicolumn{2}{|c|}{ Horizontal } & \multicolumn{2}{|l|}{ Vertical } & \multicolumn{2}{|c|}{ Horizontal } \\
\hline Type of Shale & $\begin{array}{l}\text { Applied } \\
\text { Pressure } \\
\text { (MPa) }\end{array}$ & $\begin{array}{l}\text { Average } \\
\text { Swelling } \\
\text { Potential (\% } \\
\text { strain/log } \\
\text { cycle of } \\
\text { time) }\end{array}$ & $\begin{array}{l}\text { Applied } \\
\text { Pressure } \\
\text { (MPa) }\end{array}$ & $\begin{array}{l}\text { Average } \\
\text { Swelling } \\
\text { Potential (\% } \\
\text { strain/log } \\
\text { cycle of } \\
\text { time) }\end{array}$ & $\begin{array}{l}\text { Applied } \\
\text { Pressure } \\
\text { (MPa) }\end{array}$ & $\begin{array}{l}\text { Average } \\
\text { Swelling } \\
\text { Potential (\% } \\
\text { strain/log } \\
\text { cycle of } \\
\text { time) }\end{array}$ & $\begin{array}{l}\text { Applied } \\
\text { Pressure } \\
\text { (MPa) }\end{array}$ & $\begin{array}{l}\text { Average } \\
\text { Swelling } \\
\text { Potential (\% } \\
\text { strain/log } \\
\text { cycle of } \\
\text { time) }\end{array}$ & $\begin{array}{l}\text { Applied } \\
\text { Pressure } \\
\text { (MPa) }\end{array}$ & $\begin{array}{l}\text { Average } \\
\text { Swelling } \\
\text { Potential (\% } \\
\text { strain/log } \\
\text { cycle of } \\
\text { time) }\end{array}$ & $\begin{array}{l}\text { Applied } \\
\text { Pressure } \\
\text { (MPa) }\end{array}$ & $\begin{array}{l}\text { Average } \\
\text { Swelling } \\
\text { Potential (\% } \\
\text { strain/log } \\
\text { cycle of } \\
\text { time) }\end{array}$ \\
\hline \multirow{6}{*}{$\begin{array}{l}\text { Milton Queenston } \\
\text { Shale (MQS) }\end{array}$} & 0 & $0.19(5)$ & 0 & $0.156(5)$ & 0 & $0.065(5)$ & 0 & $0.027(5)$ & 0 & $0.235(3)$ & 0 & $0.17(3)$ \\
\hline & 0.01 & $0.18(1)$ & 0.01 & $0.13(1)$ & 0.01 & $0.065(1)$ & 0.01 & $0.02(1)$ & 0.01 & $0.22(1)$ & 0.01 & $0.14(1)$ \\
\hline & 0.05 & $0.147(3)$ & 0.1 & $0.067(3)$ & 0.05 & $0.067(3)$ & 0.1 & $0.009(3)$ & 0.05 & $0.16(3)$ & 0.1 & $0.07(3)$ \\
\hline & 0.1 & $0.1(3)$ & 0.2 & $0.03(3)$ & 0.1 & $0.04(3)$ & 0.2 & $0.003(3)$ & 0.1 & $0.097(3)$ & 0.2 & $0.055(3)$ \\
\hline & 1 & $0.02(3)$ & 0.7 & $0.017(3)$ & 1 & $0.015(3)$ & 0.7 & $0(3)$ & 1 & $0.045(3)$ & 0.7 & $0.018(3)$ \\
\hline & 2.14 & $0(3)$ & 2.057 & $0(3)$ & 1.505 & $0(3)$ & 1.497 & $0(3)$ & 2.353 & $0(3)$ & 2.233 & $0(3)$ \\
\hline \multirow{4}{*}{$\begin{array}{l}\text { Niagara Queenston } \\
\text { Shale (NQS) }\end{array}$} & 0 & $0.525(3)$ & 0 & $0.21(3)$ & 0 & $0.053(3)$ & 0.000 & $0.043(3)$ & 0 & $0.39(3)$ & 0 & $0.16(3)$ \\
\hline & 0.01 & $0.515(1)$ & 0.01 & 0.205 (1) & 0.01 & 0.042 (1) & 0.01 & $0.042(1)$ & 0.01 & $0.3(1)$ & 0.01 & 0.155 (1) \\
\hline & 0.1 & $0.37(1)$ & 0.3 & $0.11(1)$ & 0.1 & $0.035(1)$ & 0.3 & $0.01(1)$ & 0.1 & $0.165(1)$ & 0.3 & $0.04(1)$ \\
\hline & 2.07 & $0(3)$ & 1.6 & $0(3)$ & 1.495 & $0(3)$ & 0.78 & $0(3)$ & 1.8 & $0(3)$ & 1.13 & $0(3)$ \\
\hline
\end{tabular}

Note: Value in brackets represents number of tests considered in calculating the average 


\section{List of Figures Captions}

1- Figure 1. X-Ray Diffraction Traces of Milton Queenston Shale and Niagara Queenston Shale: a) and c) Bulk Specimens, b) and d) Separated Clay-Size Fractions.

2- Figure 2. Preparations of Specimens and Locations of Scanning Electron Microscopy Imaging.

3- Figure 3. Scanning Electron Microscopy Images at Surfaces of Milton Queenston Shale Specimens: a) \& b) Vertical and Horizontal Sections of Specimen Soaked In Polymer Solution, c) \& d) Vertical and Horizontal Sections of Specimen Soaked In Bentonite Solution.

4- Figure 4. Scanning Electron Microscopy Images On Vertical Sections of Milton Queenston Shale: a), b), \& c) Intact Near Outer Surface, At $15 \mathrm{~mm}$, and At Centre, d), e), \& f) After 100 Days of Soaking In polymer Solution, g), h), \& i) After 100 Days of Soaking In Bentonite Solution, j), k) \& 1) After 100 Days of Soaking In Water.

5- Figure 5. Scanning Electron Microscopy Images On Horizontal Sections of Milton Queenston Shale: a), b), \& c) Intact Near Outer Surface, At 15 mm, and At Centre, d), e), \& f) After 100 Days of Soaking In polymer Solution, g), h), \& i) After 100 Days of Soaking In Bentonite Solution, j), k) \& 1) After 100 Days of Soaking In Water.

6- Figure 6. Free Swell Test on Milton Queenston Shale (MQS) in Water, Polymer and Bentonite Solutions (from M-FST22 to M-FST30): a), c) \& e) Vertical Swelling Strains, b), d) \& f) Horizontal Swelling Strains.

7- Figure 7. Free Swell Test on Niagara Queenston Shale (NQS) in Water, Polymer and Bentonite Solutions (from N-FST10 to M-FST18): a), c) \& e) Vertical Swelling Strains, b), d) \& f) Horizontal Swelling Strains. 
8- Figure 8. Semi-Confined Swell Tests on Milton Queenston Shale (MQS) in Water, Polymer and Bentonite Solutions: a), c) \& e) Vertical Swelling Strains Under Stress of 0.01, $0.1 \& 1.0 \mathrm{MPa}$; b), d) \& f) Horizontal Swelling Strains Under Stress of 0.01, 0.1 \& $0.7 \mathrm{MPa}$.

9- Figure 9. Semi-Confined Swell Tests on Niagara Queenston Shale (NQS) in Water, Polymer and Bentonite Solutions: a) \& c) Vertical Swelling Strains Under Stress of 0.01\& 0.1 MPa; b) \& d) Horizontal Swelling Strains Under Stress of 0.01, \& 0.3 MPa.

10- Figure 10. Null-Swell Tests on Milton Queenston Shale (MQS) in Water, Polymer and Bentonite Solutions: a) \& c) Null-Swell Stress in the Vertical Direction, b) \& d) NullSwell Stress in the Horizontal Direction.

11- Figure 11. Null-Swell Tests on Niagara Queenston Shale (NQS) in Water, Polymer and Bentonite Solutions: a) Null-Swell Stress in the Vertical Direction, b) Null-Swell Stress in the Horizontal Direction.

12- Figure 12. Swelling Envelopes of Milton Queenston Shale (MQS): a) In the Vertical Direction, b) In the Horizontal Direction.

13- Figure 13. Swelling Envelopes of Niagara Queenston Shale (NQS): a) In the Vertical Direction, b) In the Horizontal Direction. 


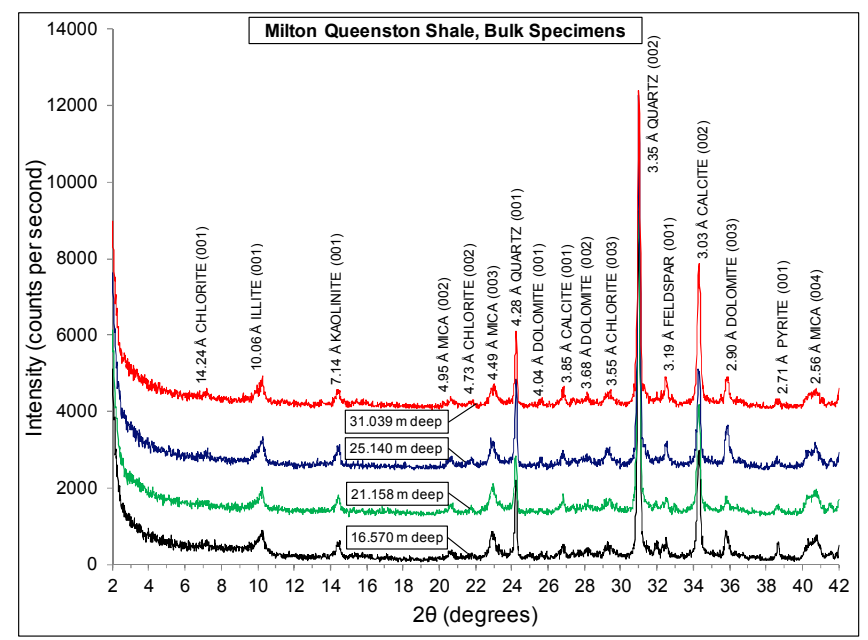

a)

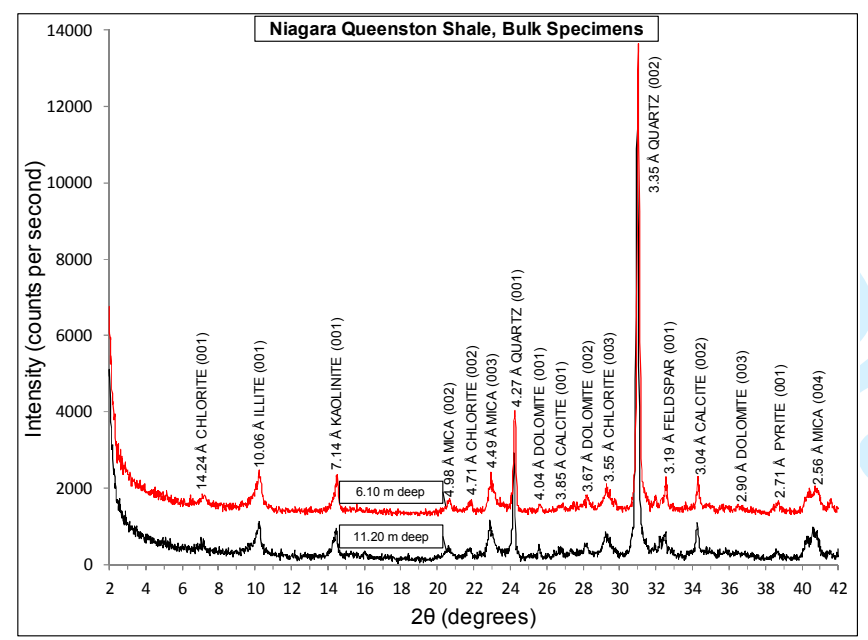

c)

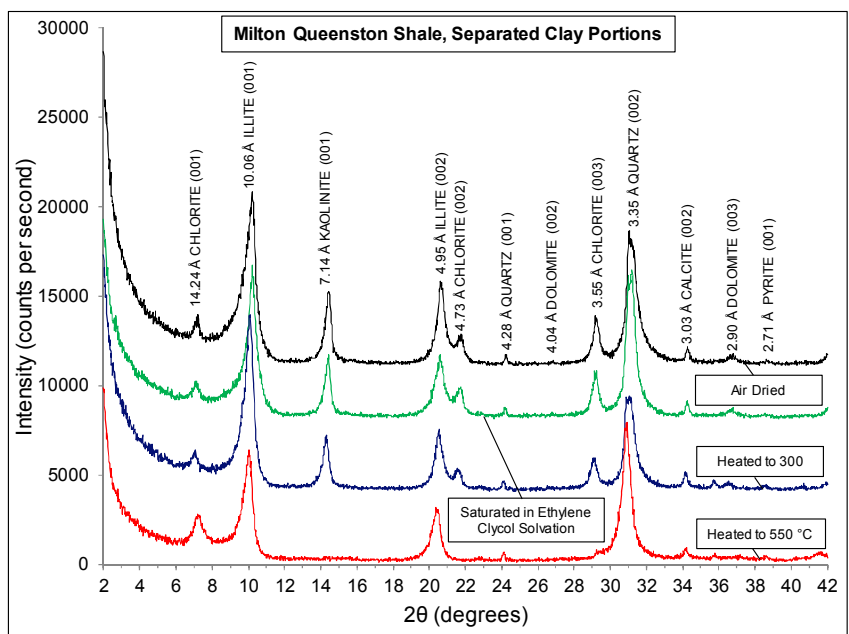

b)

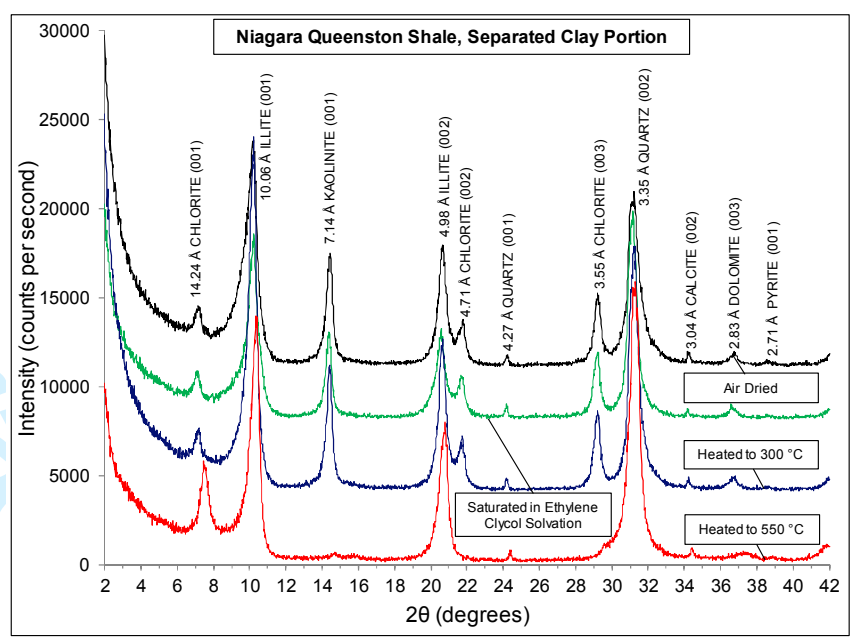

d)

Figure 1. X-Ray Diffraction Traces of Milton Queenston Shale and Niagara Queenston Shale: a) and c) Bulk Specimens, b) and d) Separated Clay-Size Fractions. 


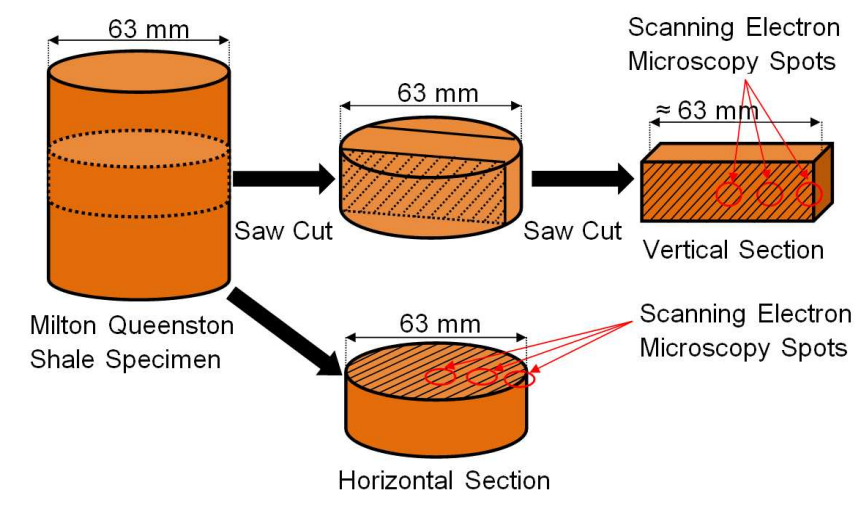

Figure 2. Preparations of Specimens and Locations of Scanning Electron Microscopy Imaging. 


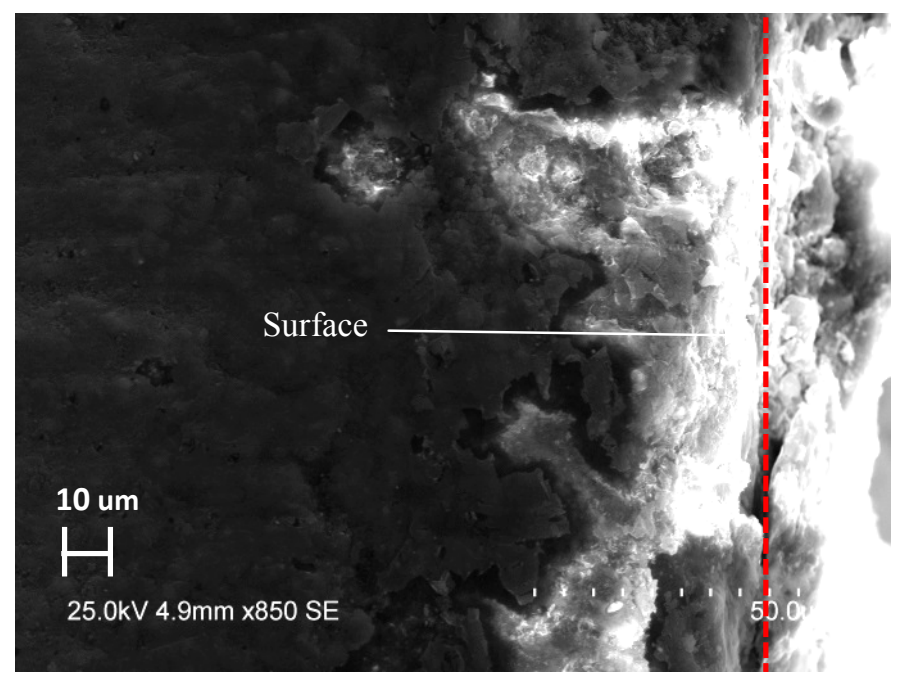

a)

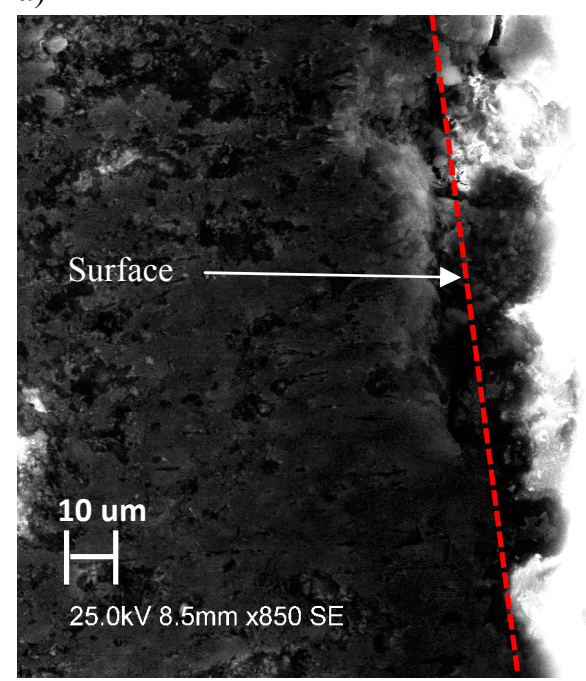

c)

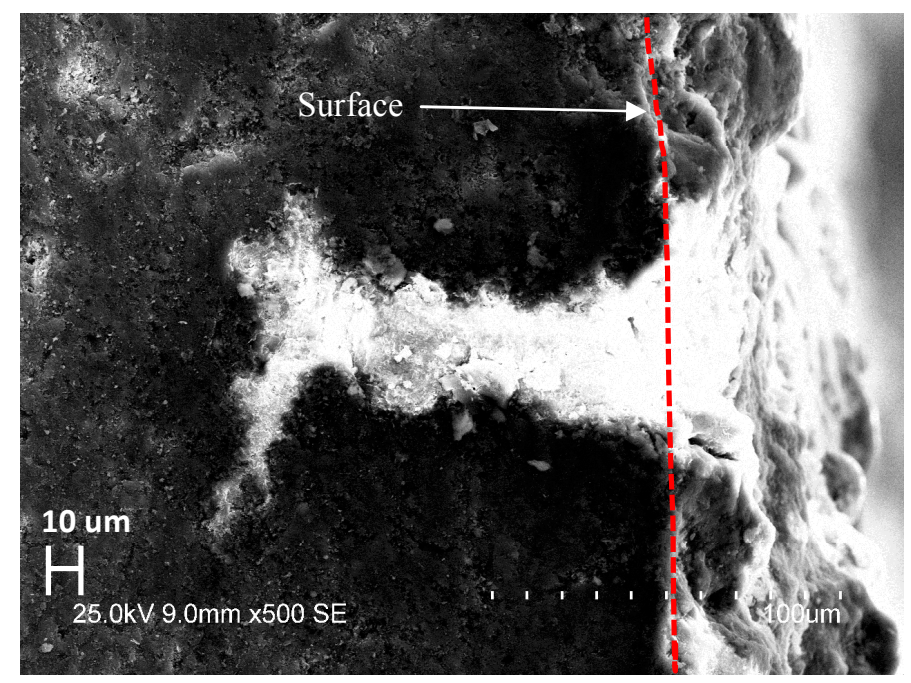

b)

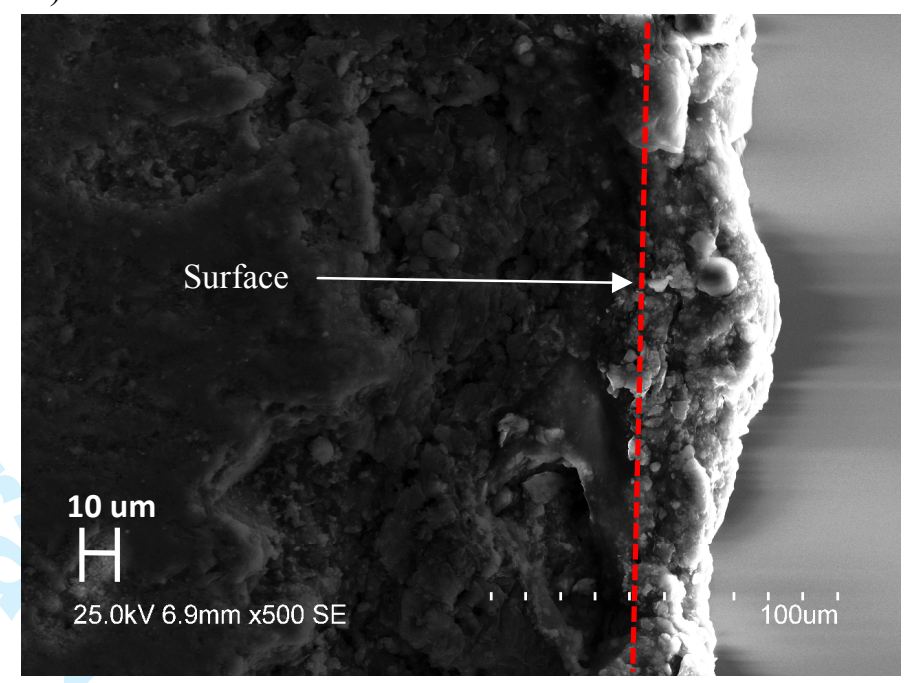

d)

Figure 3. Scanning Electron Microscopy Images at Surfaces of Milton Queenston Shale Specimens: a) \& b) Vertical and Horizontal Sections of Specimen Soaked In Polymer Solution, c) \& d) Vertical and Horizontal Sections of Specimen Soaked In Bentonite Solution. 

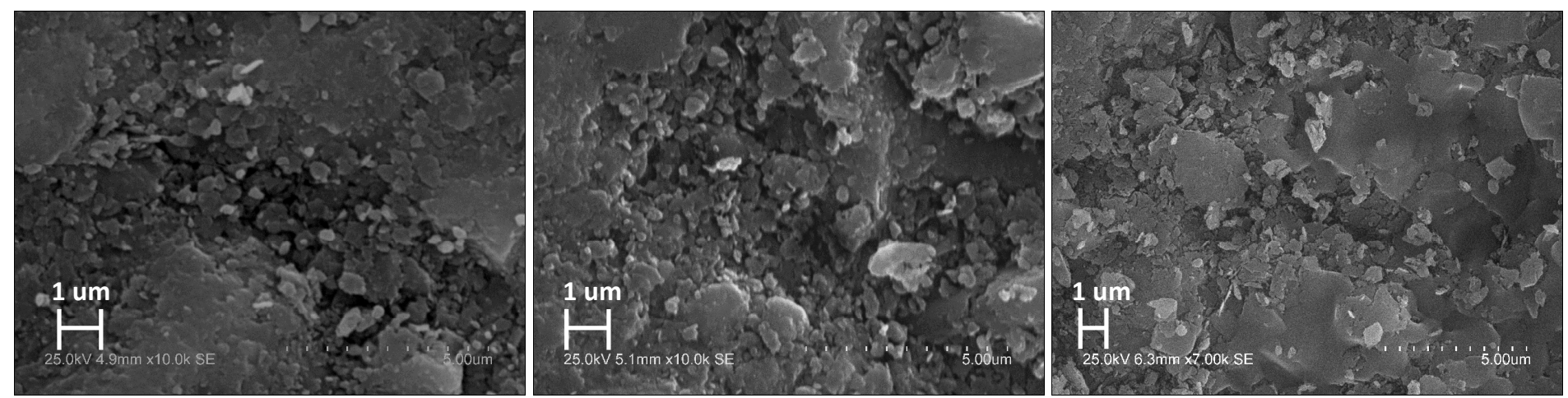

a) Intact-near the surface

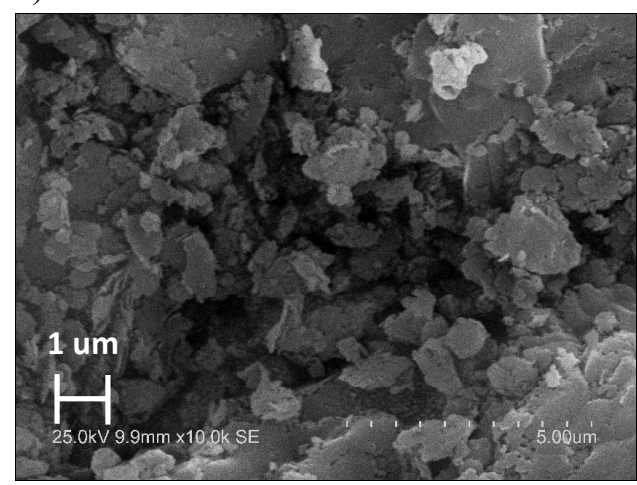

d) In polymers-near the surface

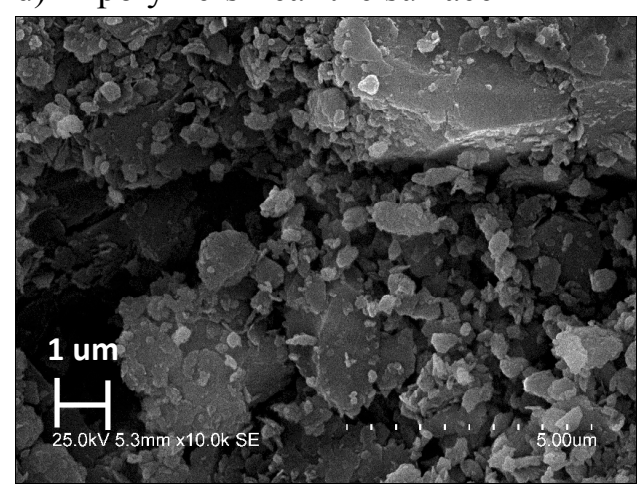

g) In bentonite-near the surface

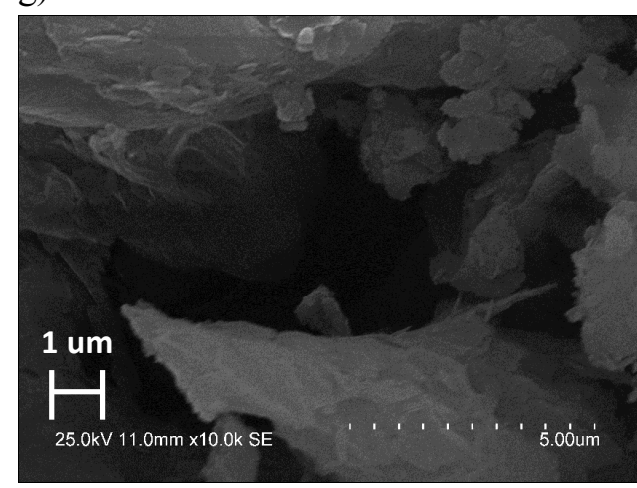

j) In water-near the surface b) Intact-15 $\mathrm{mm}$ from surface

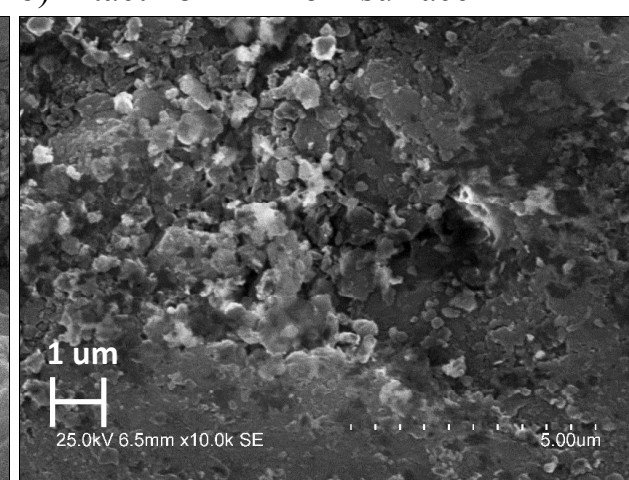

e) In polymers-15 $\mathrm{mm}$ from surface

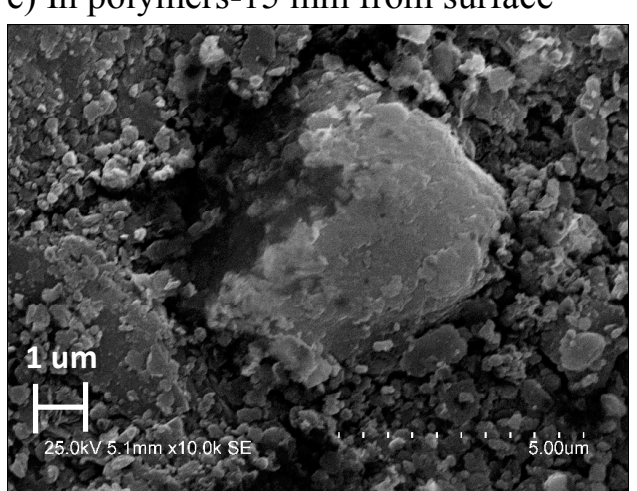

h) In bentonite- $15 \mathrm{~mm}$ from surface

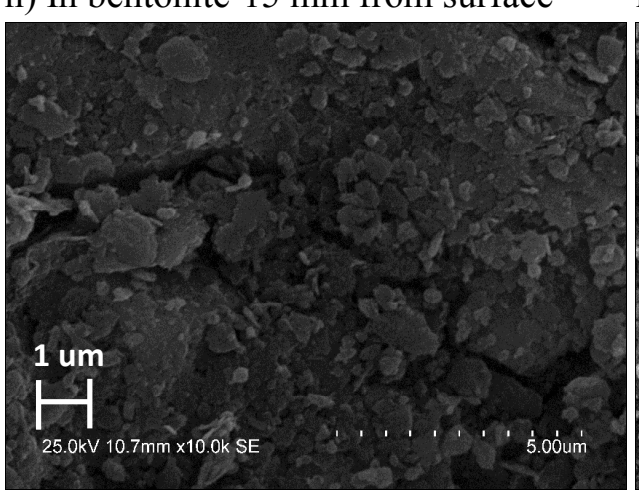

k) In water-15 mm from surface c) Intact-at the centre

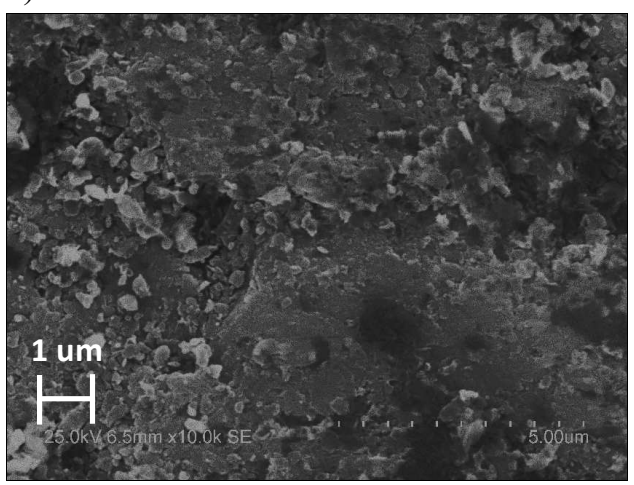

f) In polymers-at the centre

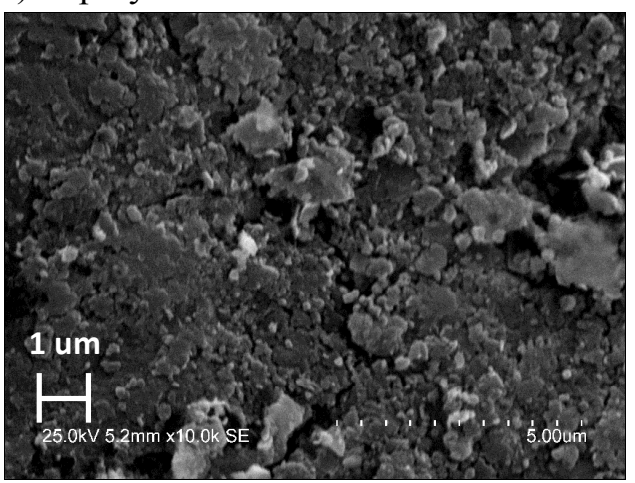

i) In bentonite-at the centre

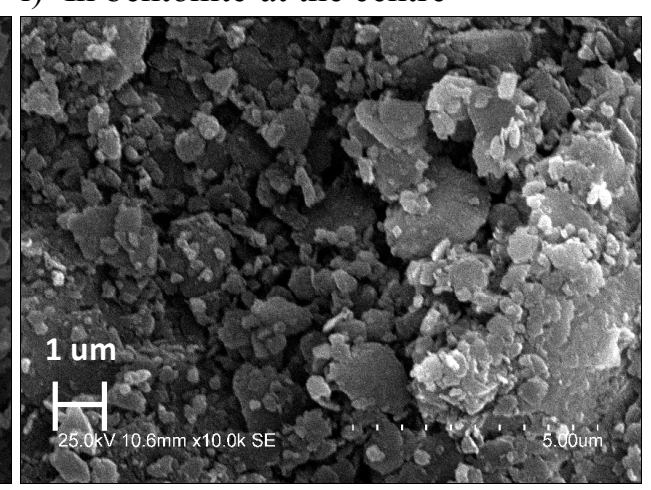

1) In water-at the centre

Figure 4. Scanning Electron Microscopy Images On Vertical Sections of Milton Queenston Shale: a), b), \& c) Intact Near Outer Surface, At $15 \mathrm{~mm}$, and At Centre, d), e), \& f) After 100 Days of Soaking In polymer Solution, g), h), \& i) After 100 Days of Soaking In Bentonite Solution, j), k) \& 1) After 100 Days of Soaking In Water. 


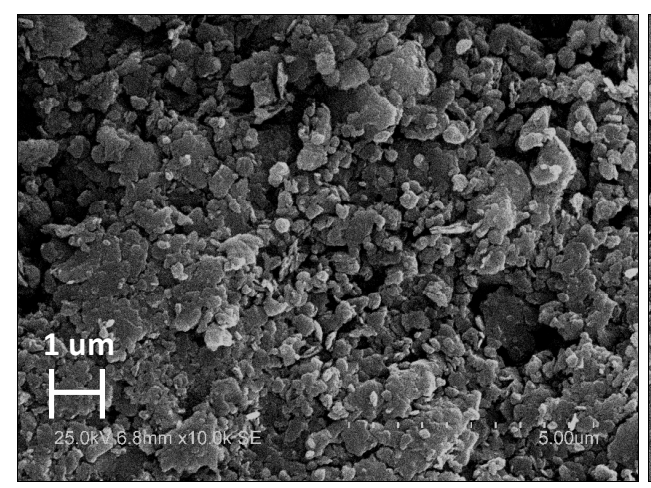

a) Intact-near the surface

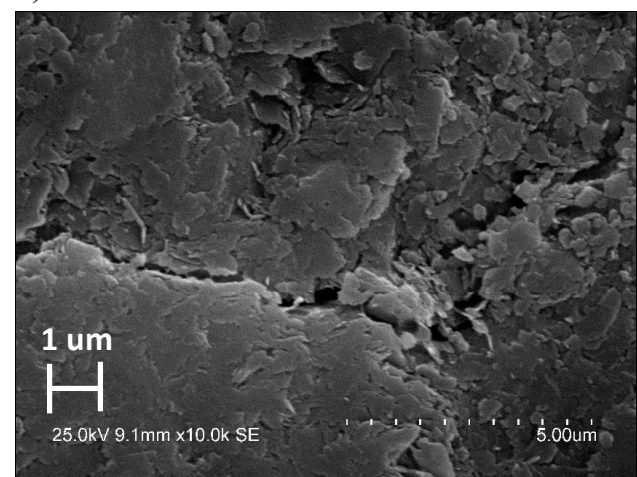

d) In polymers-near the surface

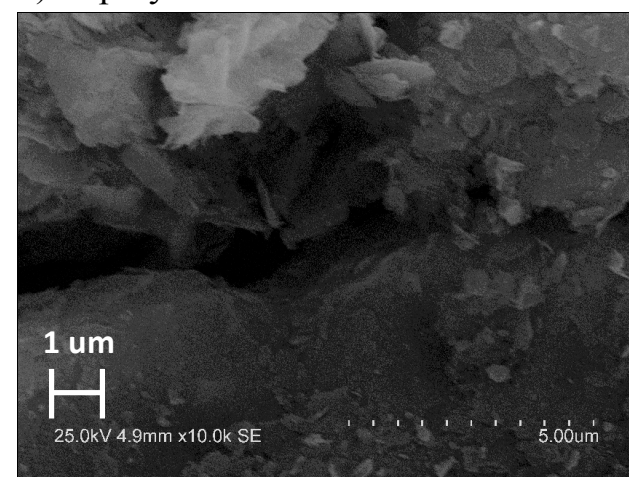

g) In bentonite-near the surface

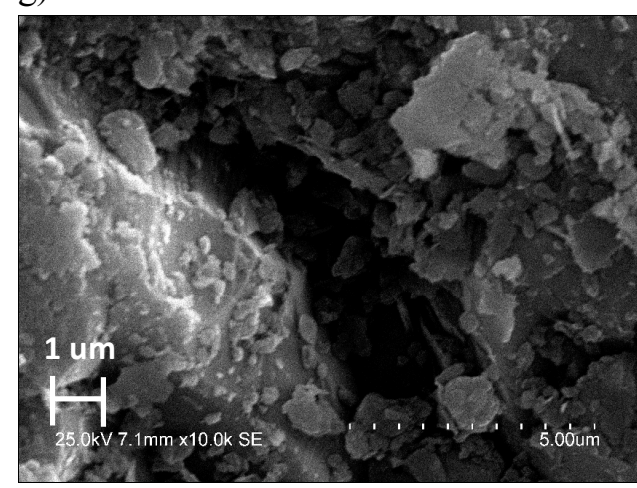

j) In water-near the surface

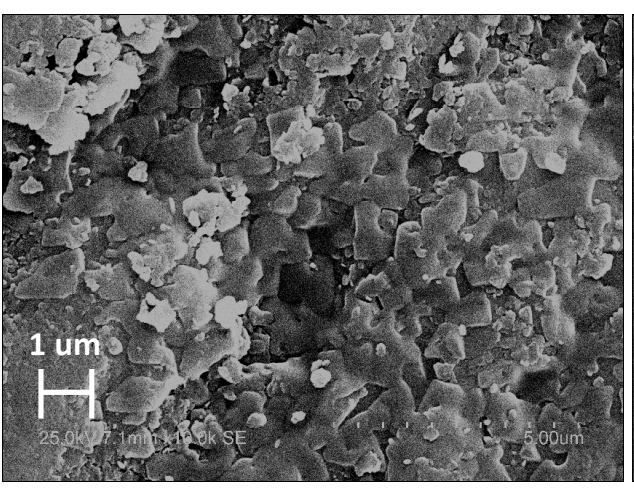

b) Intact-15 $\mathrm{mm}$ from surface

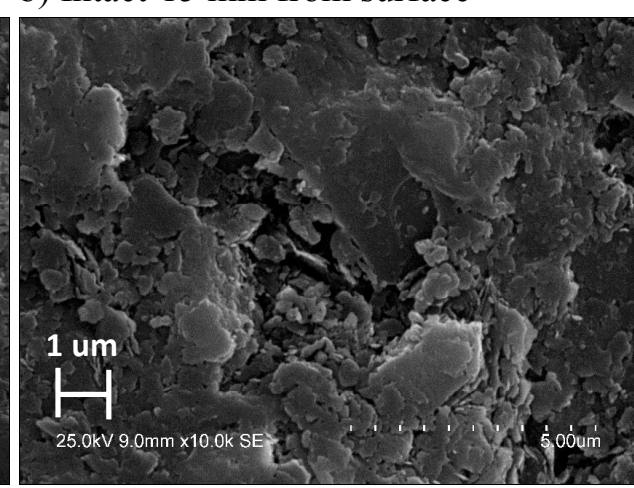

e) In polymers-15 $\mathrm{mm}$ from surface

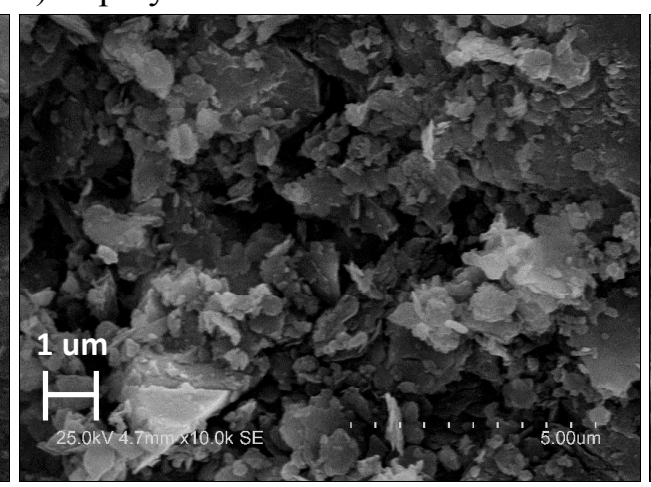

h) In bentonite- $15 \mathrm{~mm}$ from the surface

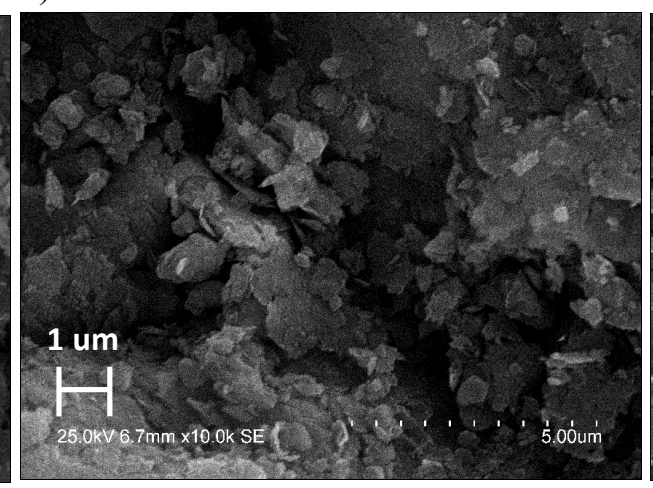

k) In water-15 mm from surface

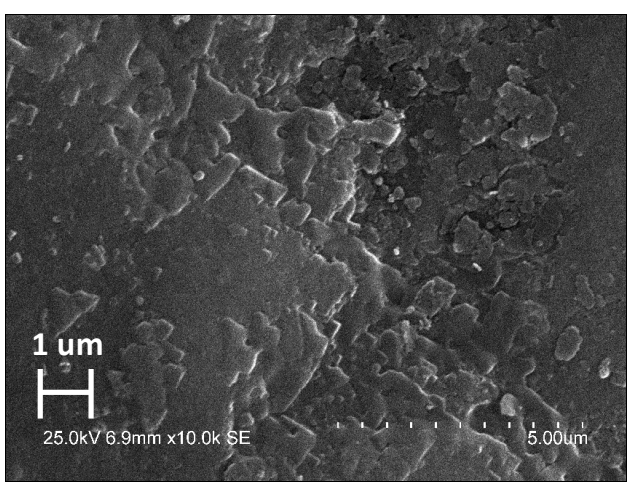

c) Intact-at the centre f) In polymers-at the centre

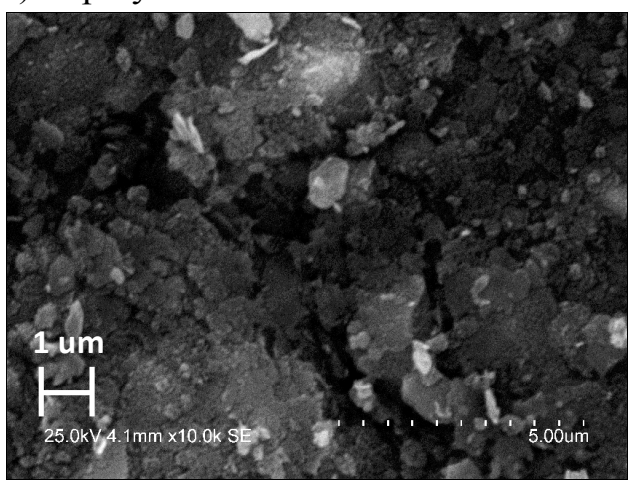

i) In bentonite-at the centre

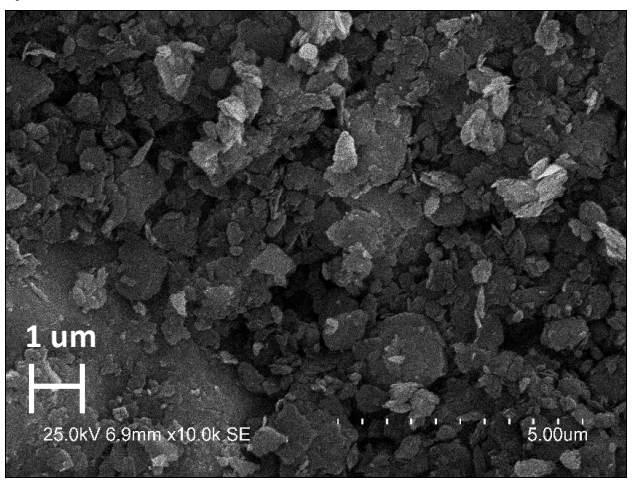

1) In water-at the centre

Figure 5. Scanning Electron Microscopy Images On Horizontal Sections of Milton Queenston Shale: a), b), \& c) Intact Near Outer Surface, At $15 \mathrm{~mm}$, and At Centre, d), e), \& f) After 100 Days of Soaking In polymer Solution, g), h), \& i) After 100 Days of Soaking In Bentonite Solution, j), k) \& 1) After 100 Days of Soaking In Water. 

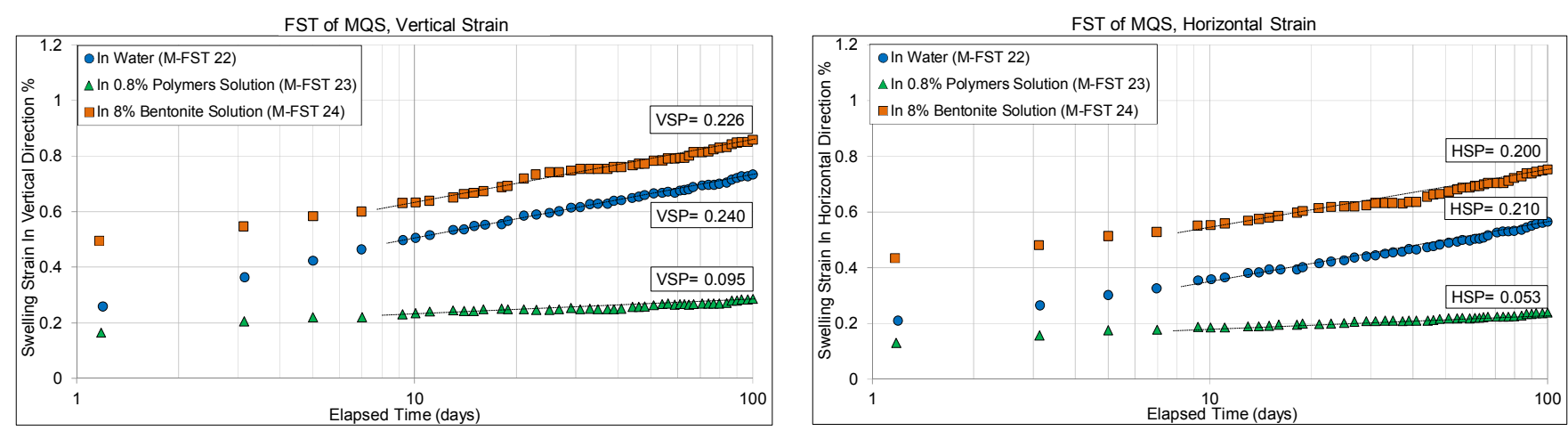

a)

b)

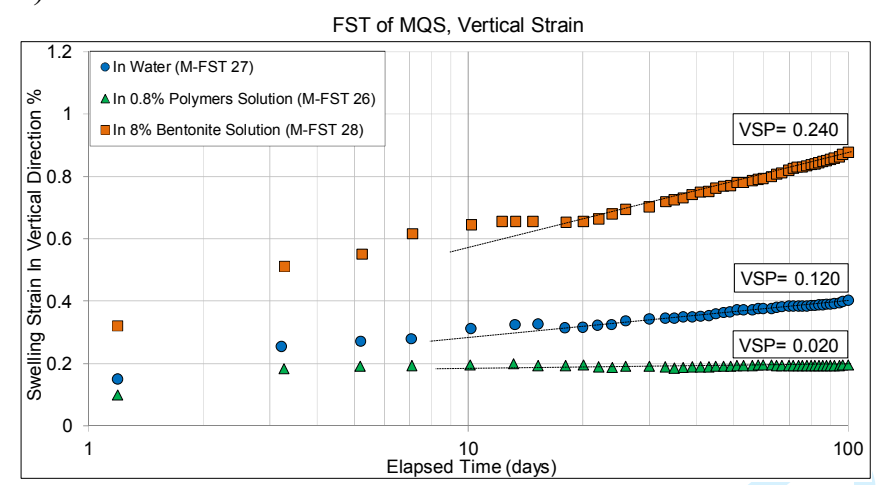

c)

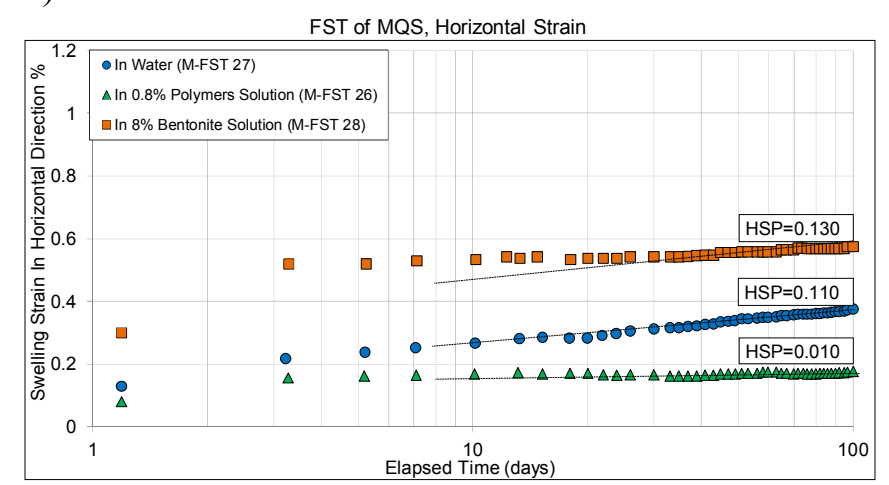

d)

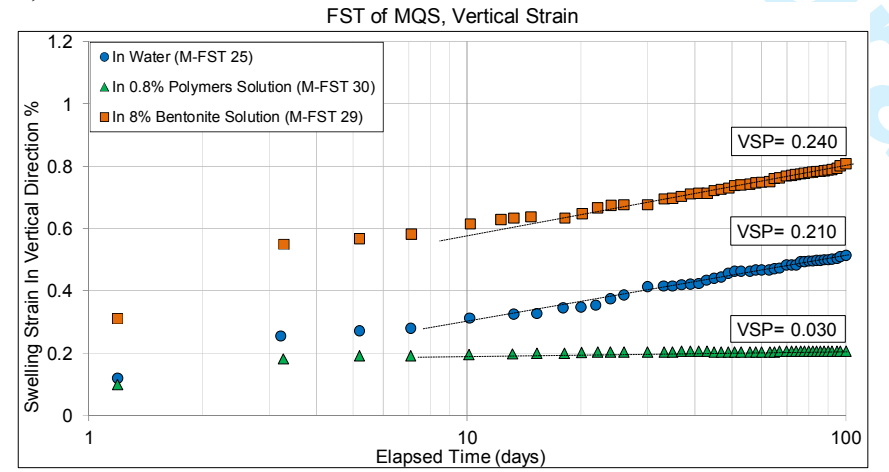

e)

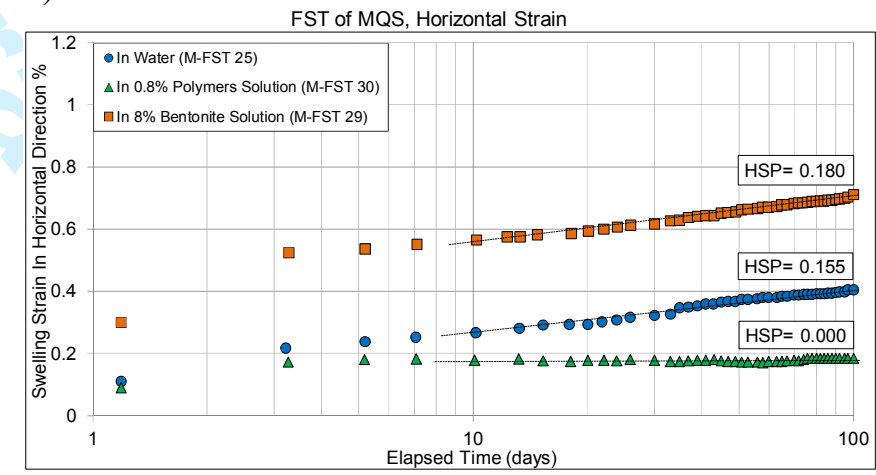

f)

Figure 6. Free Swell Test on Milton Queenston Shale (MQS) in Water, Polymer and Bentonite Solutions (from M-FST22 to M-FST30): a), c) \& e) Vertical Swelling Strains, b), d) \& f) Horizontal Swelling Strains. 

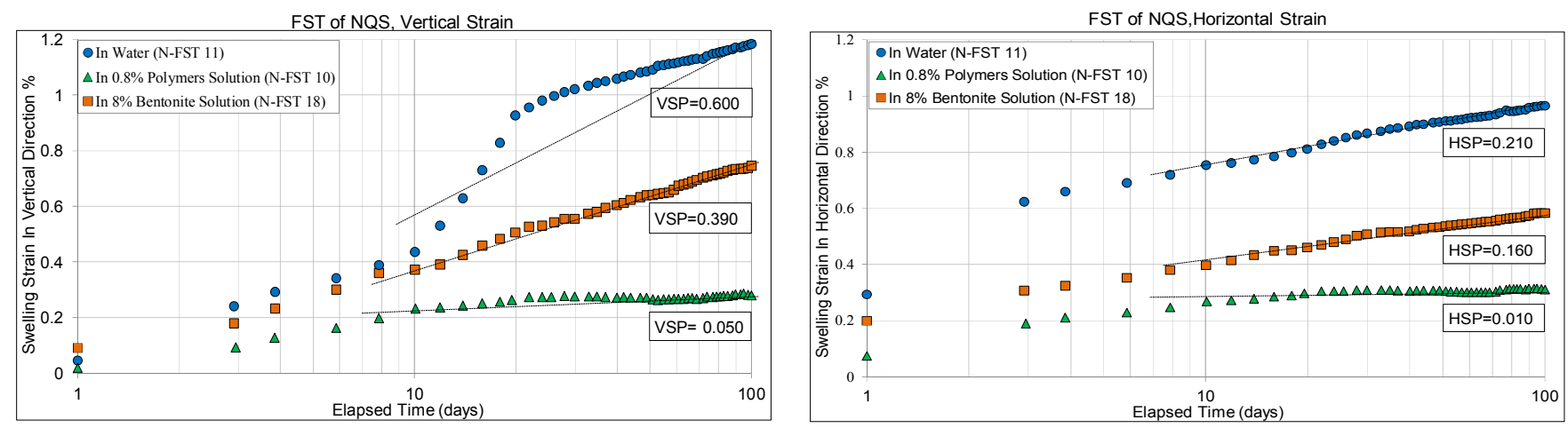

a)

b)
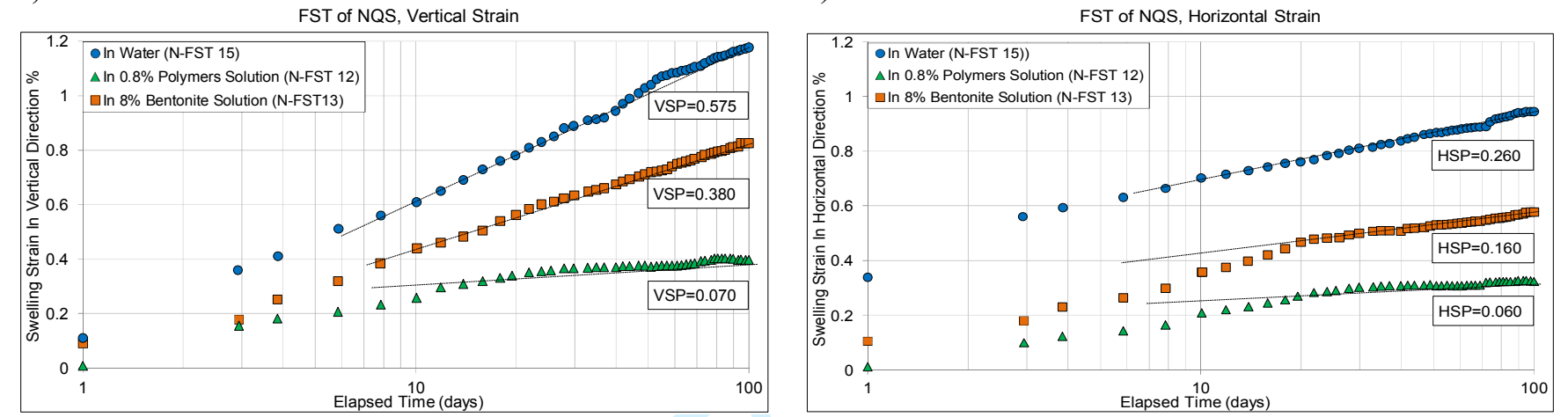

c)

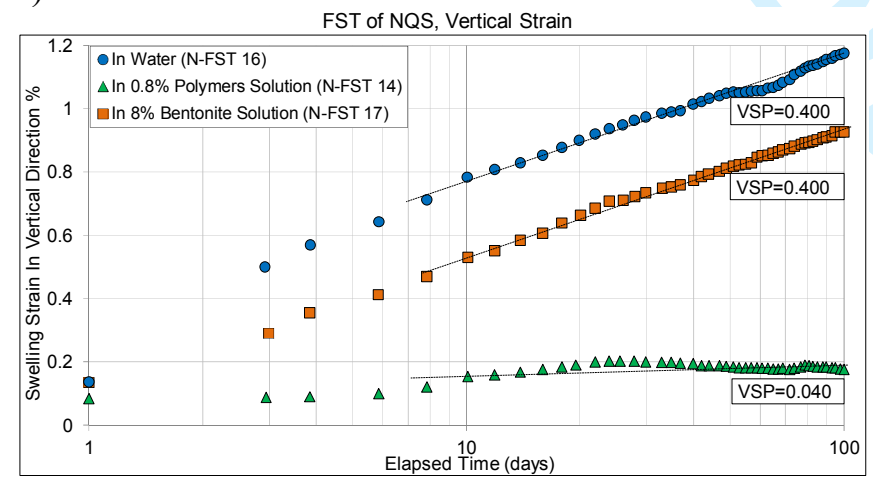

d)

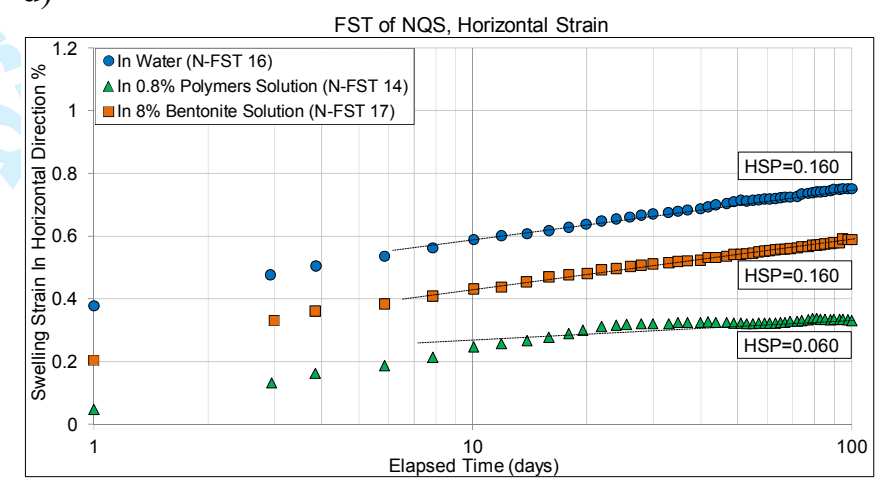

f)

e)

Figure 7. Free Swell Test on Niagara Queenston Shale (NQS) in Water, Polymer and Bentonite Solutions (from N-FST10 to M-FST18): a), c) \& e) Vertical Swelling Strains, b), d) \& f) Horizontal Swelling Strains. 
SCST of MQS Under 0.01 MPa Stress In the Vertical Direction

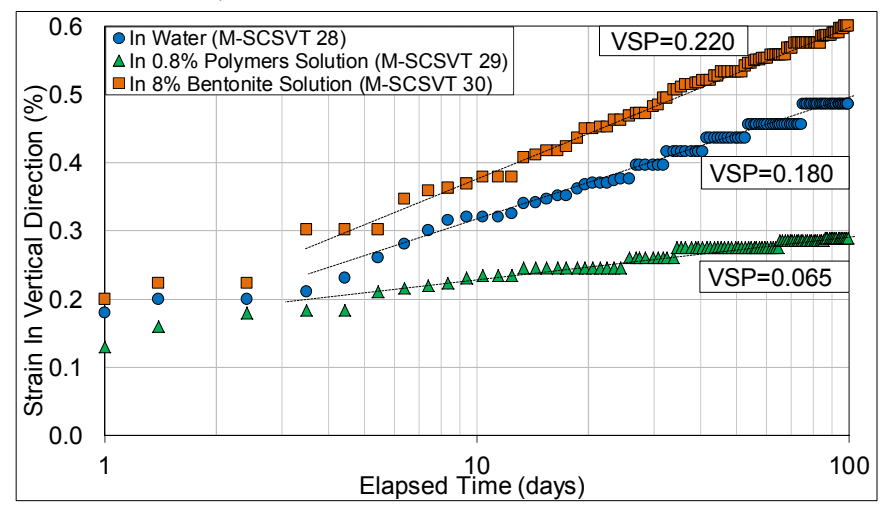

a)

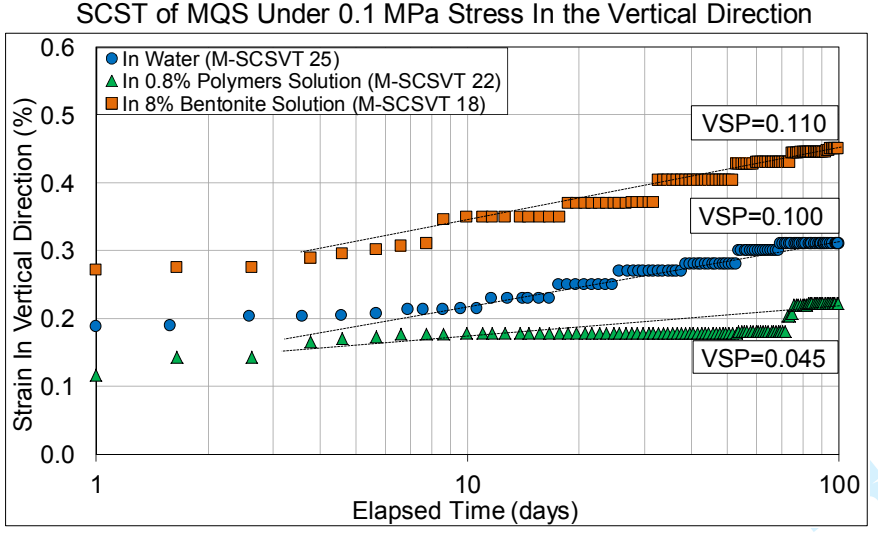

c)

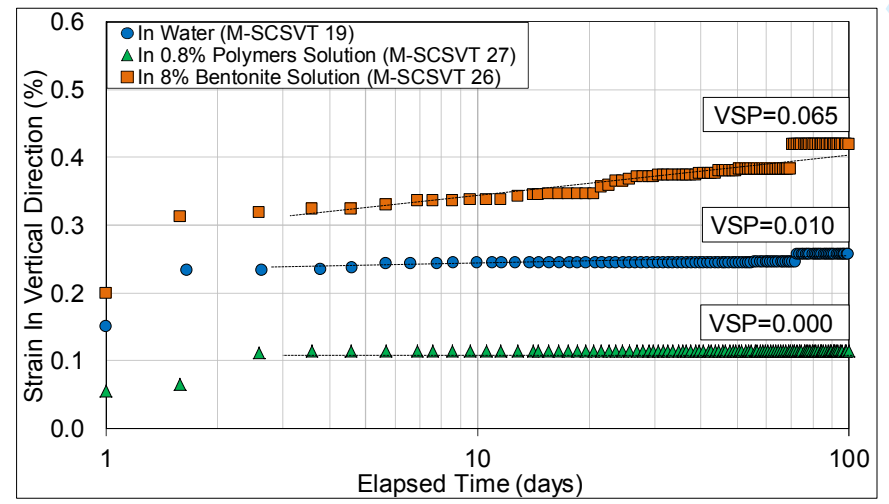

e)

Figure 8. Semi-Confined Swell Tests on Milton Queenston Shale (MQS) in Water, Polymer and

Bentonite Solutions: a), c) \& e) Vertical Swelling Strains Under Stress of 0.01, 0.1 \& $1.0 \mathrm{MPa}$; b), d) \& f) Horizontal Swelling Strains Under Stress of 0.01, $0.1 \& 0.7 \mathrm{MPa}$.
SCST of MQS Under 0.01 MPa Stress In the Horizontal Direction

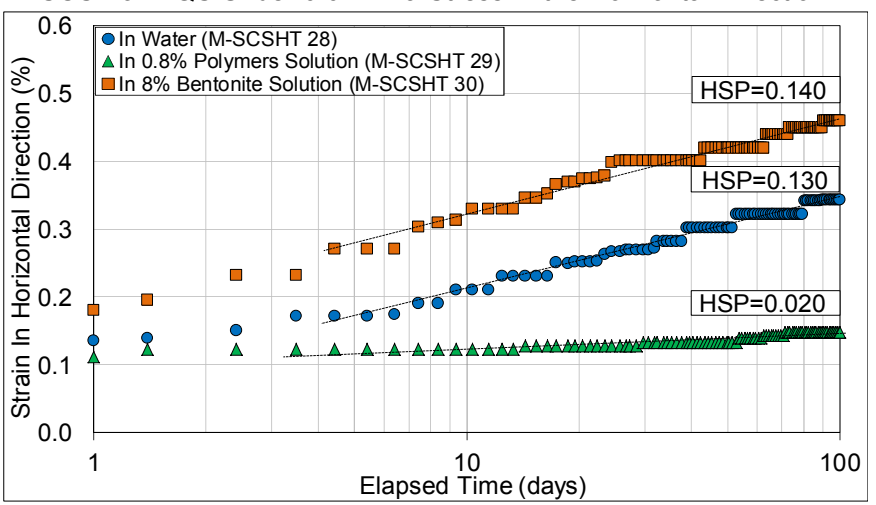

b)

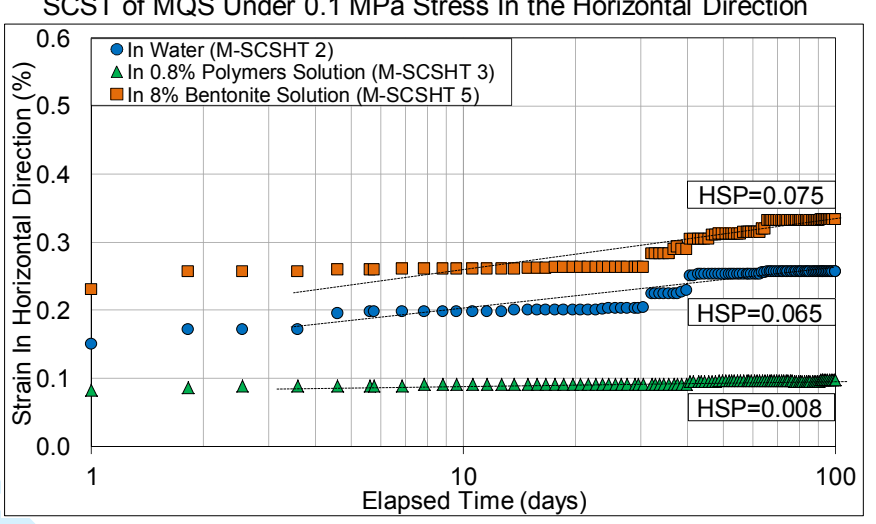

d)

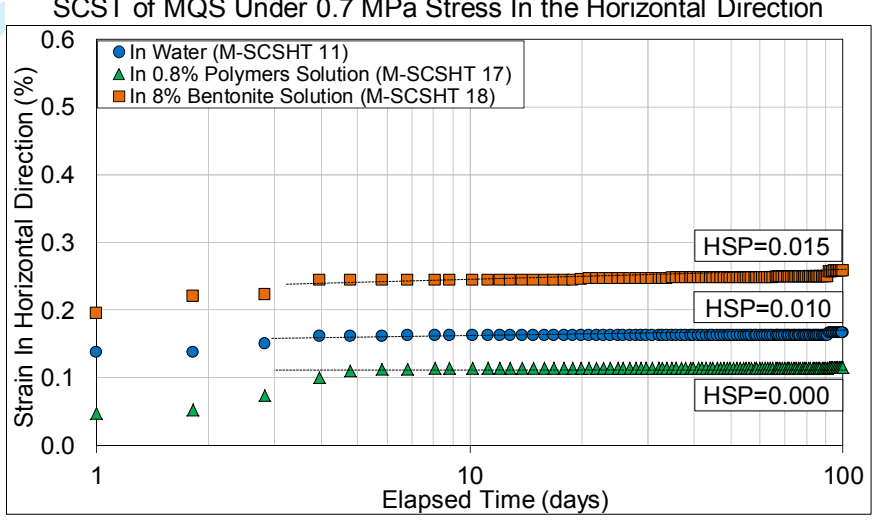

f) 
SCST of NQS Under 0.01 MPa Stress In the Vertical Direction

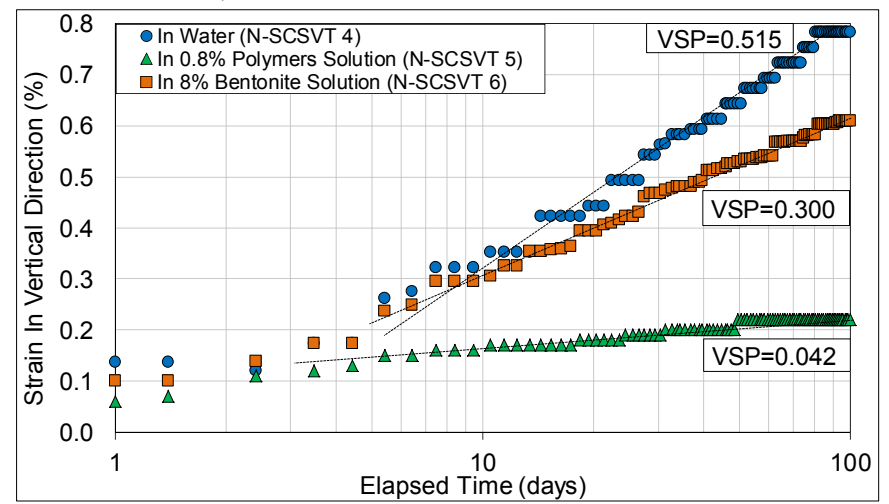

a)

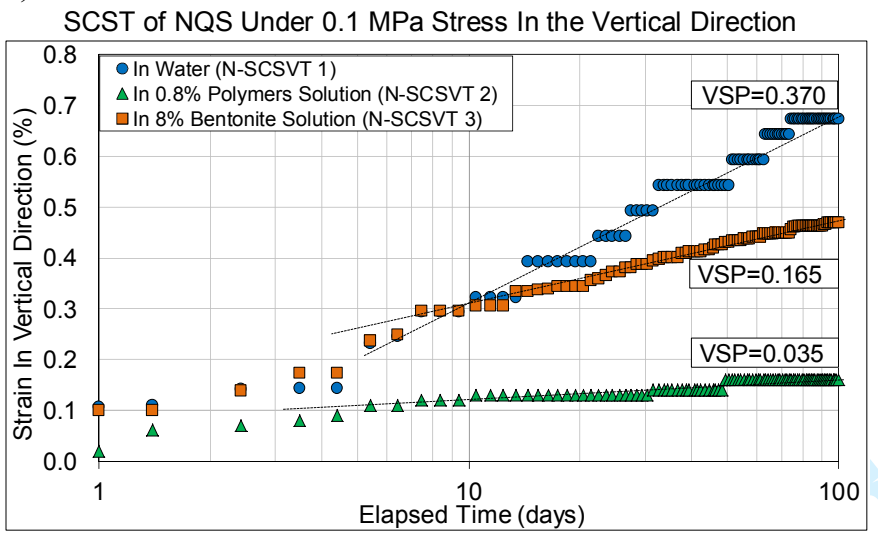

c)
SCST of NQS Under 0.01 MPa Stress In the Horizontal Direction

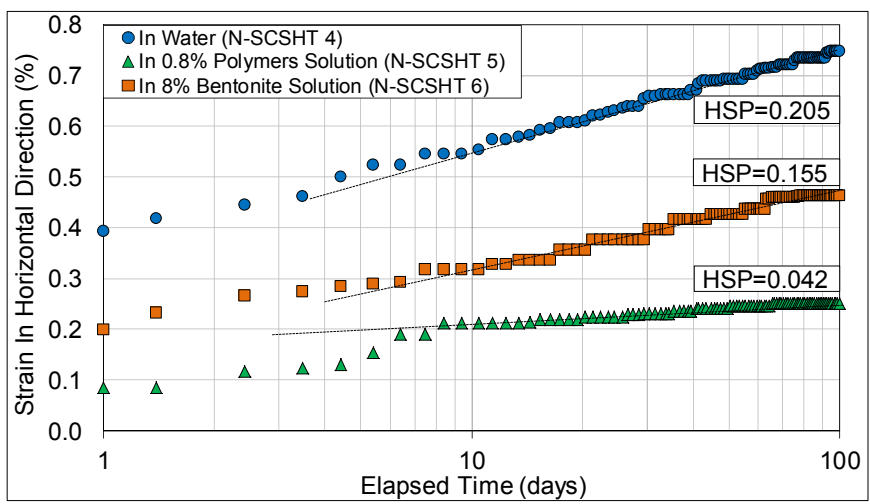

b)

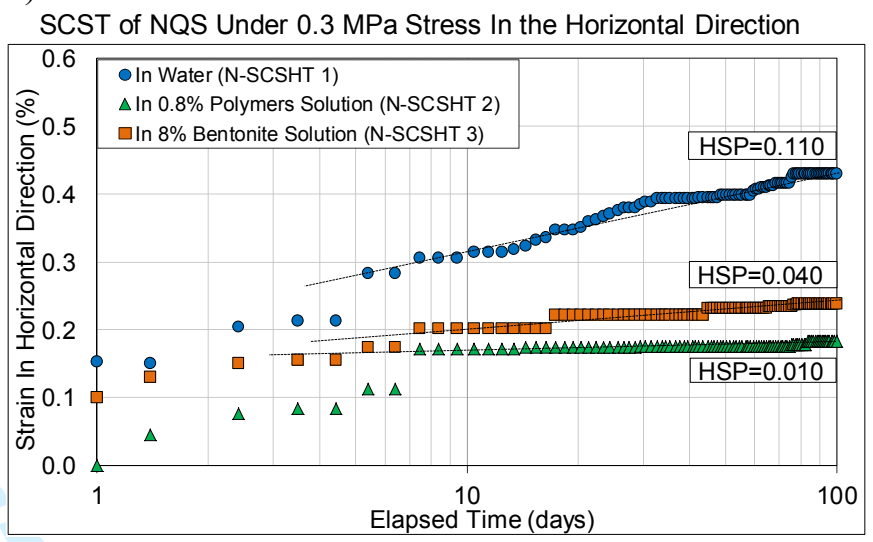

d) Horizontal Swelling Strains Under Stress of 0.01, \& $0.3 \mathrm{MPa}$. 

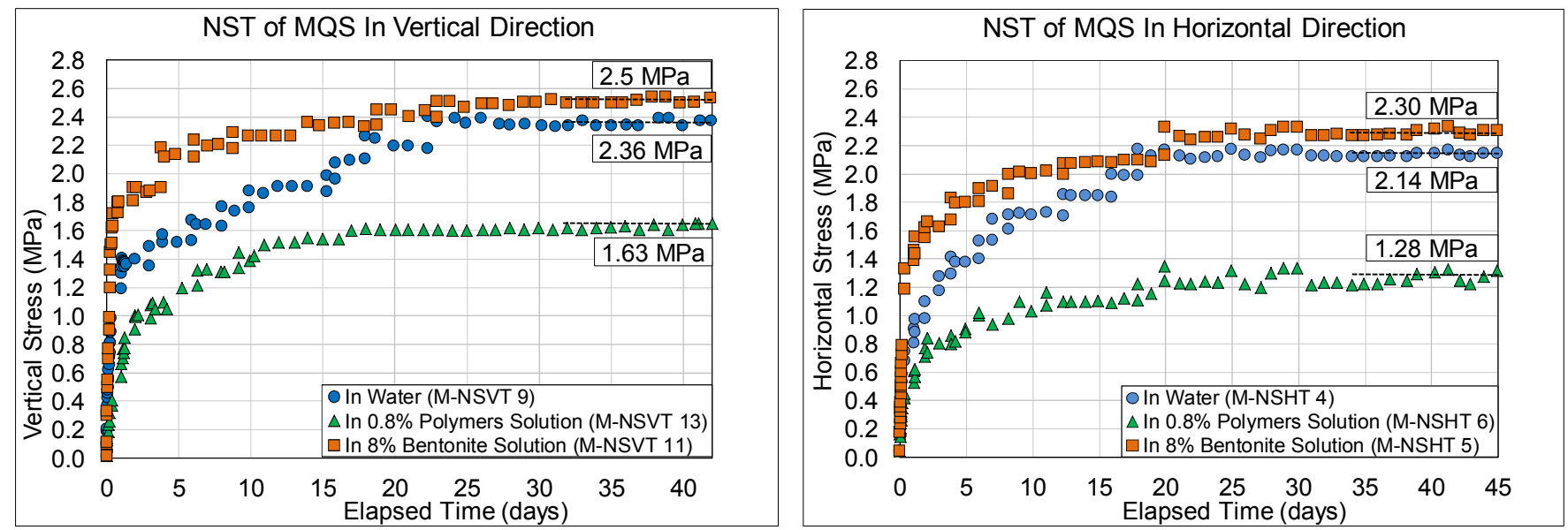

a)

b)
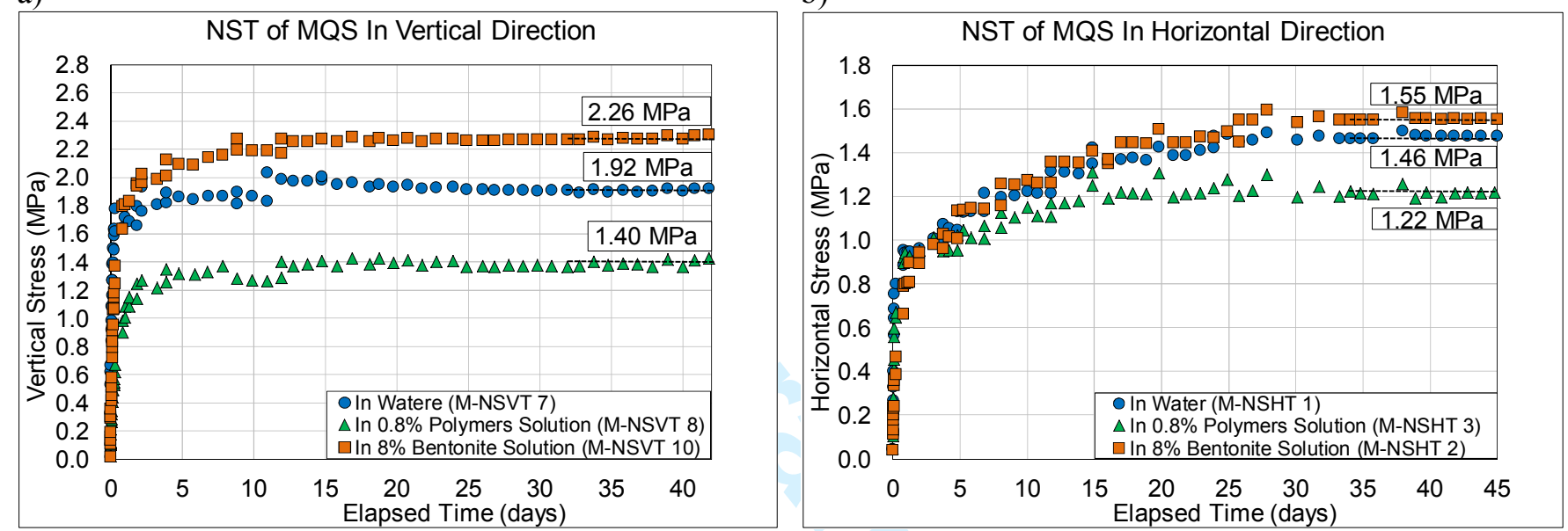

d)

Figure 10. Null-Swell Tests on Milton Queenston Shale (MQS) in Water, Polymer and Bentonite Solutions: a) \& c) Null-Swell Stress in the Vertical Direction, b) \& d) Null-Swell Stress in the Horizontal Direction. 


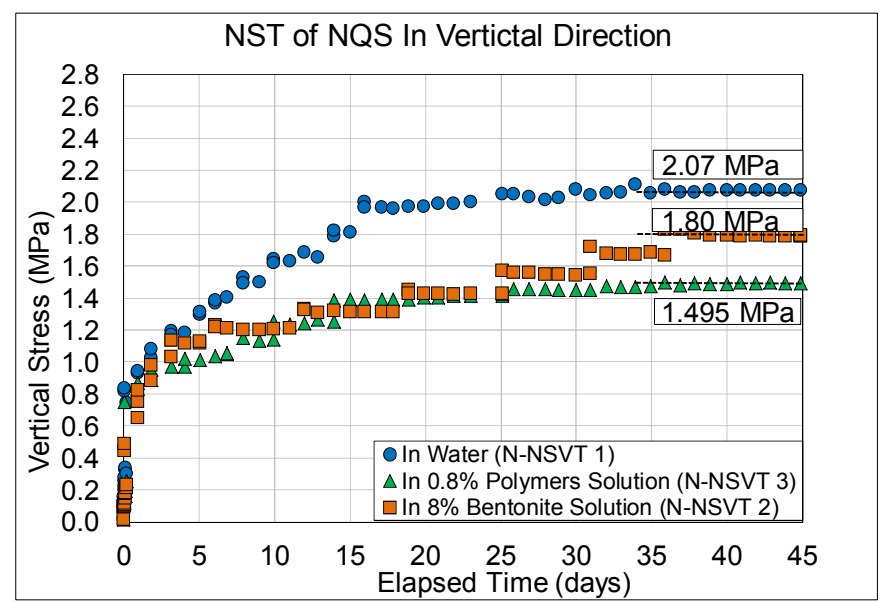

a)

Figure 11. Null-Swell Tests on Niagara Queenston Shale (NQS) in Water, Polymer and Bentonite Solutions: a) Null-Swell Stress in the Vertical Direction, b) Null-Swell Stress in the Horizontal

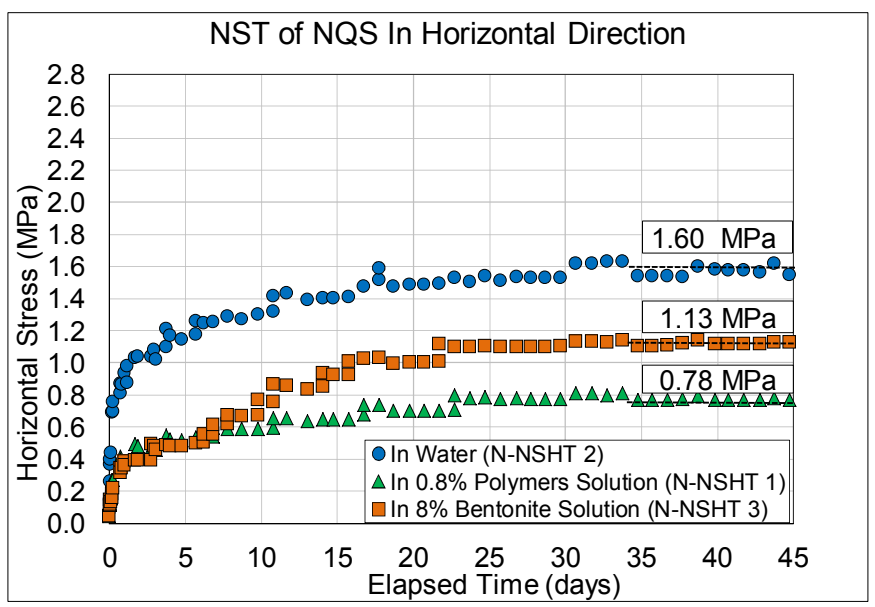

b)

Direction. 

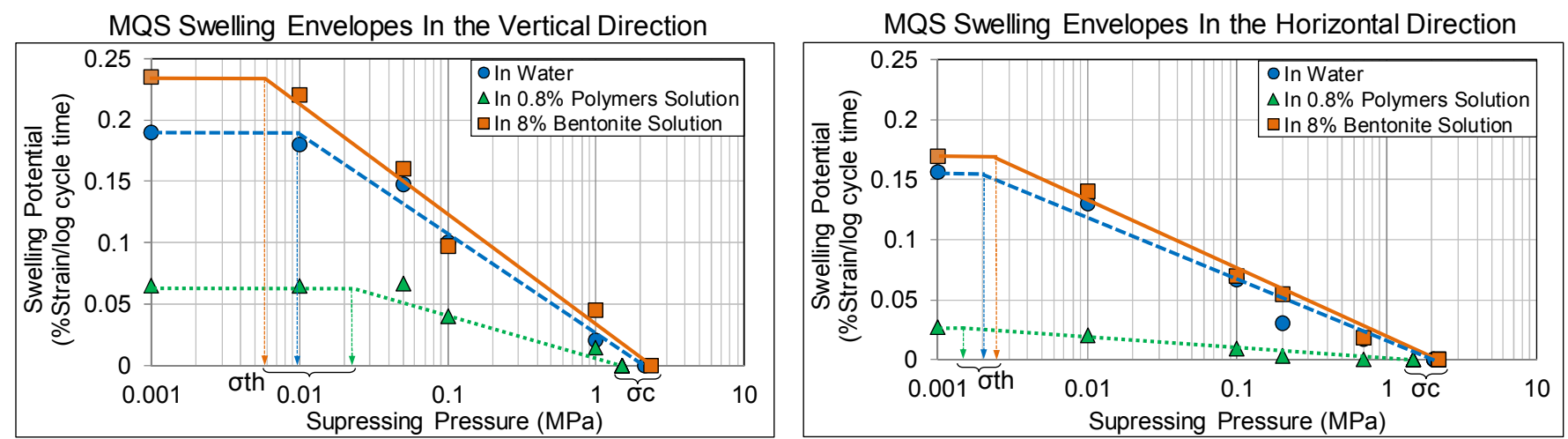

a)

b)

Figure 12. Swelling Envelopes of Milton Queenston Shale (MQS): a) In the Vertical Direction, b) In the Horizontal Direction. 
NQS Swelling Envelopes In the Vertical Direction

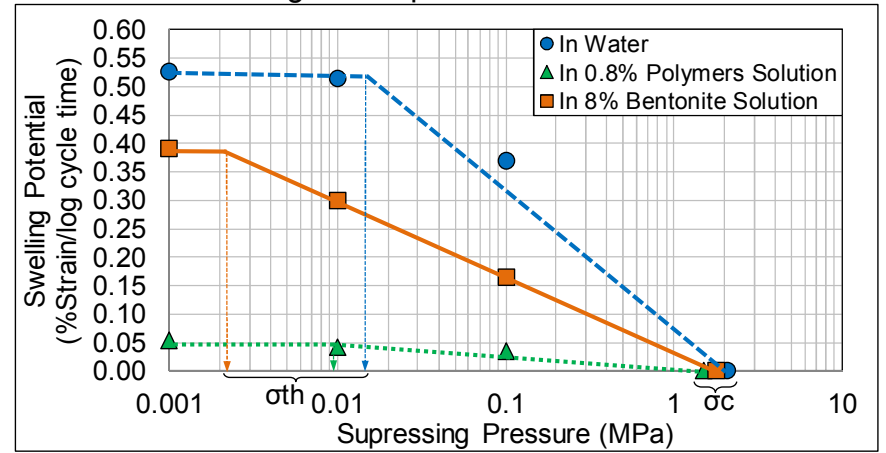

a)

Figure 13. Swelling Envelopes of Niagara Queenston Shale (NQS): a) In the Vertical Direction, b) In the Horizontal Direction.
NQS Swelling Envelopes In the Horizontal Direction

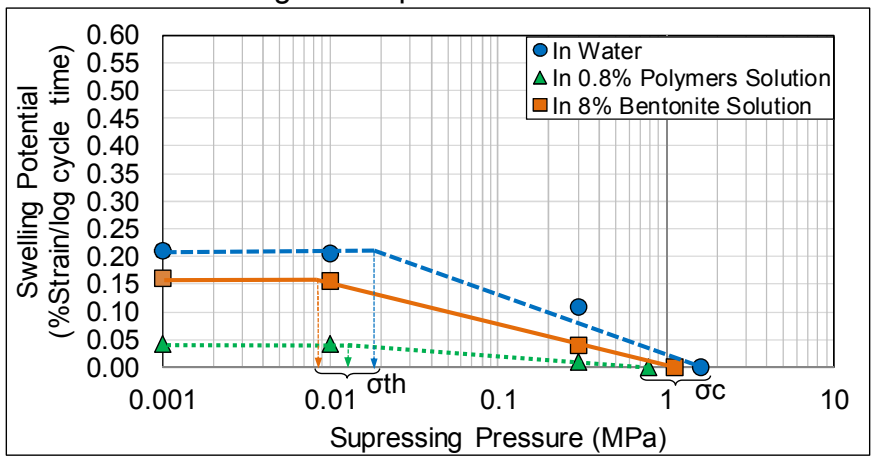

b) 